NBER WORKING PAPER SERIES

\title{
CONTRACTUAL TRADEOFFS AND SMES' CHOICE OF ORGANIZATIONAL FORM: A VIEW FROM U.S. AND FRENCH HISTORY, 1830-2000
}

\author{
Naomi R. Lamoreaux \\ Jean-Laurent Rosenthal \\ Working Paper 12455 \\ http://www.nber.org/papers/w12455
NATIONAL BUREAU OF ECONOMIC RESEARCH 1050 Massachusetts Avenue
Cambridge, MA 02138
August 2006

The authors would like to thank participants in seminars and conferences at the California Institute of Technology, Princeton University, Stanford University, the University of British Columbia, the University of Southern California, UCLA, and the UC Riverside meeting of the All-UC Economic History Group. They are grateful to Daniel Bogart, Hongbin Cai, Stephen Cullenberg, Harold Demsetz, Peter Gourevich, Timothy Guinnane, Ron Harris, Hugo Hopenhayn, Gonzalo Islas-Rojas, Kenneth Sokoloff, and William Summerhill for their detailed and helpful comments; to Juan-Francisco Aveleyra, Christopher Cook, Sarah Cullem, Alena Laptiovna, and Sarah Shen for research assistance; and to UCLA's Dean of Social Sciences, UCLA's International Institute, and the Academic Senate of the University of California, for financial support. The views expressed herein are those of the author(s) and do not necessarily reflect the views of the National Bureau of Economic Research.

(C2006 by Naomi R. Lamoreaux and Jean-Laurent Rosenthal. All rights reserved. Short sections of text, not to exceed two paragraphs, may be quoted without explicit permission provided that full credit, including () notice, is given to the source. 
Contractual Tradeoffs and SMEs' Choice of Organizational Form: A View From U.S. and French History, 1830-2000

Naomi R. Lamoreaux and Jean-Laurent Rosenthal

NBER Working Paper No. 12455

August 2006

JEL No. D21, D86, K2, K22, L22, N8

\begin{abstract}
$\underline{\text { ABSTRACT }}$
Today the vast majority of multi-owner firms in the United States are corporations, but that was not the case in the past. Before the advent of the income tax, tort litigation, and significant federal regulation, entrepreneurs more often than not chose to organize as partnerships, a form that economists consider seriously flawed. Why would they make such a terrible mistake? We begin by noting that corporations created new types of contracting problems for businesses at the same time as they solved problems afflicting partnerships. We then model the tradeoffs involved in the choice of corporations versus partnerships and confirm that the model's assumptions are consistent with U.S. legal rules up through the 1940s. The model implies that partnerships and corporations are complementary organizational forms, and we show that data from the U.S. Census of Manufactures strongly supports that implication. We also verify that the model's assumptions hold for the broader set of organizational choices available under the French Code de Commerce and use data on multi-owner firms registered in Paris in the 1830s and 1840s to demonstrate the complementary character of the basic forms. Despite much literature emphasizing the fundamentally different environments for business associated with the French and U.S. legal regimes, the basic calculus underpinning the choice of organizational form was the same in both countries.
\end{abstract}

Naomi R. Lamoreaux

Department of Economics

UCLA

405 Hilgard Avenue

Los Angeles, CA 90095-1477

and NBER

lamoreaux@econ.ucla.edu

Jean-Laurent Rosenthal

Division of Humanities and Social Sciences

California Institute of Technology

Mail Code 228-77, Pasadena, CA 91125

j1r@hss.caltech.edu 


\section{Introduction}

The vast majority of multi-owner firms in the United States today, including virtually all large-scale enterprises, are organized as corporations. Perhaps it is not surprising, therefore, that most economic theorists take the superiority of the corporate form for granted (see, for example, Williamson 1985; Hart 1995; Bolton and Scharfstein 1998; and Tirole 2001). Rather than compare the advantages and disadvantages of corporations with those of other possible organizational forms, they focus their attention on understanding the agency problems that corporations, especially large ones, routinely face (for a notable exception, see Cai 2003). A quick glance back to the beginning of the twentieth century, however, suggests that the numerical predominance of the corporation is a relatively recent phenomenon. Although then, as now, the largest firms generally were corporations, at the turn of the century the most popular form of multi-owner enterprise was the partnership. Before the advent of the income tax, before the explosion of tort litigation, before the growth of federal regulation, business people who joined together to found an enterprise more often than not chose a form of organization whose drawbacks economists consider to be both serious and obvious. Why would they make such a terrible mistake?

We approach this question by noting that the agency problems that have been the focus of so much of the economics literature afflict corporations in particular, not multi-owner firms in general (e.g., Demsetz 1972; Tirole 2001; Romano 1987; Laporta et al. 1998; and Bebchuk and Ferrell 1999). Problems of delegated management and minority oppression arise precisely because the corporate form concentrates power in a small group of officers. Partnerships do not have these problems because each member of the firm has full ownership rights. Of course, 
partnerships have other problems that follow from this characteristic of joint control. Most obviously, they suffer from the possibility that disputes will arise among the firm's various owners and disrupt its operations or, even worse, force what was otherwise a successful enterprise to dissolve. Economists have tended to view these flaws as nearly fatal to the form (see, for example, Blair 2003). Hence there has been little effort in the literature to model organizational choice as a tradeoff between the flaws of partnerships, on the one hand, and those of corporations, on the other. ${ }^{1}$

In this paper we take on this modeling task. In effect, we ask the question: if business people's decisions were not biased by exogenous factors such as tax or regulatory policy, what would govern their organizational choices? We focus initially on the choice between partnerships and corporations because these were the main options available to business people in the U.S. (and in other countries with Anglo-American legal regimes). Then, however, we examine the expanded set of organizational choices available to business people in France under the Code de Commerce (and in other countries with similar code-based legal systems). We find that the trade-offs among these various organizational forms differed in degree but not in kind from those available under Anglo-American law. In other words, despite much literature emphasizing the fundamentally different environments for business associated with these alternative legal regimes (see especially La Porta et al. 1997 and 1998), the basic calculus underpinning the choice of organizational form was the same.

The paper is organized as follows. Section II frames the theory by isolating the essential differences between the partnership and corporate forms. Section III develops our model of

\footnotetext{
${ }^{1}$ Legal scholars have not all been so dismissive of partnerships. For a defense of the form, see Ribstein 2005. Hansmann and Kraakman (2000) take an intermediate position. In their view, the essential characteristic of a business entity is that it must be able to partition the assets of the firm from those of the people who make it up.
} 
organizational choice. In Section IV we confront the model with the legal rules and quantitative evidence for the U.S. in the nineteenth and early twentieth centuries. Then in Section V we do the same for France. For both countries we find that the legal rules support the model's key assumption that corporations and partnerships address different governance problems. We also find strong quantitative evidence for the model's main implication that partnerships and corporations were complements rather than substitutes. In both countries very large firms were more likely to be corporations than partnerships, but owners of small- and medium-size firms seem to have weighed the advantages of one form over another, sometimes deciding in favor of partnerships and sometimes corporations. Their choices varied both within and across industries, suggesting that owners based their decisions on their own individual characteristics, as well as on the types of business in which they were engaged.

\section{Framing the theory}

In 1892 Andrew Carnegie and about a score of other businessmen organized the Carnegie Steel Company, Ltd. Capitalized at \$25 million, the company included four major steel plants, several iron furnaces and mills, two coke works, and an assortment of other properties. In other words, it was a very large concern and, by that standard, might have been expected to organize as a corporation. But the associates chose instead a complicated form of partnership that was in some respects similar to today’s limited liability company (Wall 1970, 321-22, 535-37).

This choice of organizational form presents an intriguing puzzle. The company had large, firm-specific investments that could not be liquidated easily. At the same time, none of the partners, except perhaps Carnegie himself, had human capital that was critical to the enterprise's

Partnerships accomplished this purpose, but corporations did so more securely. See also Hansmann, Kraakman, and 
success. According to the arguments of Williamson, Hart, Demsetz, and other theorists, Carnegie Steel should have been organized as a corporation. But it was not, and the choice was not a matter of accident or oversight. The associates had to seek out expert legal assistance to draft the firm's complicated partnership contract. That they did so in a period when organizing a corporation was a simple, routine matter suggests that they thought there were severe drawbacks to the corporate form.

Although relatively few firms this large organized as partnerships, the Carnegie example is a useful way of highlighting the broader phenomenon with which we are concerned: the continued, widespread use of the partnership form decades after the passage of general incorporation laws. Of course, the corporate form was also adopted by large numbers of firms during this period, but it was not nearly as dominant as it would become during the late twentieth century. Clearly, although some business people thought corporations were a better way of organizing their enterprises than partnerships, others came to just the opposite conclusion. Our problem is to understand the tradeoffs that these choices involved.

Because both partnerships and corporations were broadly popular, it does not make sense to think of the two organizational forms as pure substitutes, with the corporation an overwhelming improvement over the partnership. To be sure, a key advantage of incorporation was that it enabled firms to raise funds on the equities markets. Some firms (railroad companies, for example) required so much capital that this ability was critical to their success. But in the nineteenth century relatively few corporations ever carried out a public offering or listed their stock on an exchange. If access to capital markets was the primary motivation for incorporation, then there should have been at most a few thousand rather than hundreds of thousands of

Squire 2006. 
corporations in the United States (Navin and Sears 1955; Baskin and Miranti 1997; Lamoreaux

and Rosenthal 2005).

Corporations also benefited from limited liability, but this advantage could raise the cost of borrowing to the firm. Indeed, in order to gain access to credit most corporations depended on their stockholders personally to endorse their debts. ${ }^{2}$ Although the need to secure stockholders' voluntary assent meant that members of corporations could control the extent of their obligations in a way that was not possible in partnerships, it also made it more difficult for the firm to act expeditiously. In other words, limited liability was not an unalloyed boon but imposed costs that could affect the firm's access to credit and its flexibility in making decisions.

The tradeoffs associated with the choice to incorporate were even starker where internal governance was concerned. Governance problems arise whenever the manager of a firm does not own it outright. Given that most individuals have limited wealth and credit, many enterprises necessarily have more than one owner. As a result, they face a variety of transaction costs. In an ideal world one might imagine that business people could devise sophisticated contracts that would enable them to eliminate all transaction costs, regardless of which organizational form they chose. Yet even if such contracts existed, it is not obvious that founding entrepreneurs would adopt efficient governance rules. As Bebchuck (2002) has shown asymmetric information may lead founding entrepreneurs deliberately to choose poor governance arrangements. As a point of fact, moreover, the literature has identified a slew of real-world problems that firms

\footnotetext{
${ }^{2}$ For this reason, the credit reports gathered by R. G. Dun \& Co. typically assessed the creditworthiness of a corporation's major stockholders, as well as the firm itself. See, for example, the 2 December 1869 entry for the Gorham Manufacturing Co. in Rhode Island: "Since the Senior Gorham's death + the consequent deprivation of his endorsement their credit has been weakened." Rhode Island vol. 9, R. G. Dun \& Co., Baker Library, Harvard Graduate School of Business Administration. Shareholders in large corporations might also be called upon to bear responsibility for debts. See Bain $(1999,133)$ for an account of how Collis Huntington, Leland Stanford, Charles Crocker, and Mark Hopkins all had to endorse personally the obligations of the Central Pacific when the company was building its half of the first transcontinental railroad. See also Hurst 1964, 414, 862, and note 104; Hurst 1970, 28; and Forbes 1986.
} 
cannot easily contract away. These include providing managers with the incentives to work hard enough to insure the project's success (Hart 1995), giving stakeholders the incentive to monitor management's activities (Demsetz 1972; Zweibel 1995; Bolton and Von Thaden 1998), accommodating members' desire to withdraw from the firm if conflicts over strategy arise (Lamoreaux and Rosenthal 2006), and limiting the extent to which majority owners or managers can extract private benefits of control (Tirole 2001).

The general assumption in the literature is that the corporation is more efficient in reducing these kinds of transaction costs than the partnership, except for a small number of unusual industries or exceptional firms. Alchian and Demsetz (1972) emphasize the inefficiencies that follow from the partners' joint control, the weakened incentive to exert effort and the relative ineffectiveness of monitoring. In Hart's model of partnerships (1995), there is no joint control—each partner exercises authority over a different set of assets—but joint ownership implies shared returns, which in turn reduce the incentives of either partner to make discretionary investments in the assets they control. When these authors turn to corporations, however, they sweep all the multi-owner problems away. Alchian and Demsetz assume the corporation's hierarchy is an efficient mechanism to induce effort. In Hart's model of the corporation the managers make investment decisions as if they owned the whole firm.

These assumptions about corporations are clearly wrong. Although a corporation does have delegated management, it remains a multi-owner firm. Hence the incentives facing the manager of a corporation cannot be the same as those of a sole proprietor. Indeed, this last observation lies at the core of the burgeoning literature on corporate governance, which highlights the conflicts that arise within corporations between shareholders and managers, on the one hand, and among different factions of shareholders, on the other (Tirole 2001; Demsetz and 
Lehn 1985; Pagano and Roell 1998). For some scholars, the solution to conflict between shareholders and managers is large block holders (Demsetz 1972; Zwiebel 1995). According to this view monitoring is both non-contractible and costly, so only the investor with the largest stake in the firm will do any monitoring and that investor must own a big chunk of the firm to be willing to monitor at all. Other scholars, however, have argued that dominant block holders play a more ambiguous role. Large shareholders will want to use their control rights for private gain, and unless they own nearly all the firm, they will increase their earnings at the expense of other shareholders (Zingales 1995; Yarrow 1985). The problem is a serious one because charters often give control either to a particular group of stockholders (through dual class shares or special voting schemes) or to professional managers (through poison pills or staggered boards). As a result, control is often exercised by individuals who own just a small fraction of the firm and yet have the capacity to extract private benefits. As the scandals of the late 1990s revealed, the extent of their extraction can be significant indeed.

These problems of corporate governance are rooted in the form's legal history, for the business corporation was originally adopted to solve a key problem of the partnership form: the likelihood that otherwise profitable enterprises would suffer untimely dissolution. ${ }^{3}$ Legally, partnerships had no existence or identity that was independent of the specific individuals who formed them. If any partner died or decided to withdraw from the business, the firm had to dissolve. Although a variety of legal devices could be employed to limit the damage a partner's withdrawal could cause (Ribstein 2005), these arrangements were cumbersome and often of uncertain enforceability (Lamoreaux and Rosenthal 2006). ${ }^{4}$ Moreover, the problem was

\footnotetext{
${ }^{3}$ For a recent strong restatement of this argument about the origins of corporations, see Blair 2003.

${ }^{4}$ Dissolution did not necessarily mean liquidation, of course. It was possible for the remaining partners to buy out a withdrawing member and continue the business on their own. Once a course was set for dissolution, however, there was always the risk that liquidation would be necessary if the partners could not agree on a buyout price or if there
} 
particularly onerous for firms with many owners because the likelihood of a death or crippling dispute among the associates increased with the number of partners.

Corporations were able to solve the problem of untimely dissolution because they were legal persons that existed without regard to the identity of their shareholders. Shareholders might withdraw from the enterprise by selling their stakes, but they could not force the firm to refund their investments, and they had no power to act on behalf of the enterprise. Corporations were run by officers and a board of directors duly elected by the firm's membership. Although in principle these officers and directors served at the pleasure of shareholders, during their terms in office they had considerable leeway to act as they saw fit. Moreover, because replacing management always required a substantial ownership stake — half the shares or moredisgruntled shareholders typically found them difficult to depose.

Management's ability to extract private benefits was thus enshrined in the very essence of the corporation. To make matters worse, any individual (or group of individuals willing to act in concert) who acquired half or more of the firm had the power to require management to do its bidding. Hence the problem of disciplining management could easily become the more difficult problem of disciplining controlling shareholders. Whereas disgruntled minority stakeholders could force a partnership to dissolve, they had no similar power in a corporation. As a result, whoever was in control could make decisions with little regard to the interests of other members of the firm and even expropriate some of the minority's earnings (Lamoreaux and Rosenthal 2006).

were not enough ready assets to make a payoff possible. If, as a consequence, firm-specific assets had to be sold, the cost to the partners was potentially very high. 


\section{The basic model}

In this section we examine these essential differences between partnerships and corporations using a simple static model. We reduce the number of parties to two: an entrepreneur/manager and an investor. The entrepreneur contributes a business plan, a specific amount of wealth, and work effort. She is not rich enough to carry out the project on her own. The investor can provide the extra capital the entrepreneur needs if it worth his while. More formally, we assume that the entrepreneur has an idea that requires 1 unit of capital to realize. If the project succeeds, it earns $\Pi$; if it fails, it earns L. (L can be thought of as the liquidation value of the project.) If funded, the project succeeds with probability $\mathrm{p}$, which depends on the effort the entrepreneur exerts. For now we assume there is an efficient level of effort that will generate a probability of success $\mathrm{p}^{*}$. The entrepreneur's opportunity cost for the efficient level of effort is $\mathrm{w}$, which is paid as a wage. Therefore, the return to the project will be $\mathrm{R}=\mathrm{p} \Pi+[1-\mathrm{p}] \mathrm{L}-\mathrm{w}$. We assume that $\Pi$ is large enough that for some $\mathrm{p}$ the project is socially valuable $(\mathrm{R}>1+\mathrm{r}$, where $\mathrm{r}$ is the rate of interest). The entrepreneur is risk neutral and has a wealth level $\mathrm{W}_{\mathrm{e}}<1$. To finance the project she turns to an investor, who is also risk neutral and has limited wealth. Indeed, if organizational form is going to matter, the associates must face wealth constraints. Otherwise, one or the other of them can operate the firm as a sole proprietorship. The model has three periods. In each period only one player moves. Each player's decisions are all observable to the other player, so we can restrict our analysis to pure strategies.

In period one the entrepreneur (who we assume "owns" the idea for the project) decides on the organizational form (corporation or partnership), the stake to offer the investor, and her own wage. We define a partnership to be a firm under the joint control of the partners. Hence the capacity of a partner to act is not related to his or her equity stake. We define a corporation to be 
a firm that is controlled by the majority shareholder. That is, whoever owns the larger equity stake can act as a dictator. If the investor is the controlling shareholder, he can determine how the entrepreneur will manage the firm. In period two the investor decides whether or not to accept the entrepreneur's offer and whether or not to monitor the entrepreneur's effort in period three. ${ }^{5}$ If the investor does not participate, the project is not undertaken and the game ends. If the project is undertaken, then in period three the entrepreneur chooses her effort level if the investor does not monitor. If the firm is organized as a corporation, whoever is the controlling shareholder decides whether to extract private benefits. Then profits (or losses) are realized and distributed among the owners.

We assume that neither the investor nor the entrepreneur can commit to future actions at the beginning of play. When contracting on organizational form and equity distribution, the entrepreneur cannot commit to provide the efficient level of effort. Similarly, the investor cannot commit to monitor the entrepreneur to prevent her from shirking. If the firm is organized as a partnership, the associates cannot commit to staying in the business. If the firm is organized as a corporation, the controlling stockholder cannot commit not to extract private benefits. However, the decisions that the entrepreneur makes about organizational form and the distribution of equity in period one will determine which of these various problems are likely to afflict the firm.

Solving the model always involves comparing the returns to partnerships with those to corporations. Our analysis proceeds in three steps. We begin by considering the choice of organizational form when the firm faces only one transaction cost. We replicate the standard finding of the literature that, if there is only one type of transaction cost, one organizational form

\footnotetext{
${ }^{5}$ This assumption (that the investor can commit to a monitoring decision in period two) is made for simplicity-to insure that the model has a pure strategy equilibrium. It would be more realistic to assume that the investor cannot commit and that monitoring and effort are chosen simultaneously. It is easy to show that our model would then have a mixed strategy equilibrium that is analogous to the pure strategy equilibrium.
} 
will dominate over the other. We also show, however, that whether partnerships or corporations prevail depends on the nature of the transaction cost. We then move on to consider organizational choice when there are several transaction costs and equity stakes are given. In this part of the paper, we in effect analyze the model's last two periods first in order to characterize the fundamental advantages and disadvantages of the two organizational forms. In the final step, we consider the joint choice of equity stakes and organizational form when the investor and the entrepreneur together have just enough capital to start the business $\left(\mathrm{W}_{\mathrm{e}}+\mathrm{W}_{\mathrm{i}}=1\right)$. This step allows us to show that both organizational forms continue to have advantages and disadvantages when transaction costs matter and capital markets are imperfect. Finally, we consider what happens to these choices when capital constraints are relaxed.

\section{III.A. When only one transaction cost is present}

\section{III.A.1. Shirking.}

Even though the entrepreneur earns a wage such that she is willing to exert the optimal level of effort, she will shirk unless she has the proper incentives. We consider the two classic ways of inducing effort: giving the entrepreneur a sufficient equity interest in the firm; and monitoring her activities.

Take the case of equity first. We assume that the entrepreneur's effort increases with her ownership share $S$ in such a way that $p(S)$ is concave and the efficient level of effort, $p^{*}=p(1)$. Denote the socially efficient return, $p^{*} \Pi+\left[1-p^{*}\right] \mathrm{L}-\mathrm{w}$ by $\mathrm{R}^{*}$. We assume that $\mathrm{R}^{*}=\mathrm{R}(1)>(1+\mathrm{r})$ and $\mathrm{R}_{0}(0)<(1+\mathrm{r}) .^{6}$ If the only motivation to effort is the entrepreneur's stake, then the return to

\footnotetext{
${ }^{6}$ The entrepreneur cares about income and but dislikes effort. In the absence of monitoring, her effort choice depends upon the tradeoff between effort $(E)$ and the return to her equity stake $(Y)$. $U(Y,-E)=U(S[p(E) \Pi+[1-$
} 
the firm will be $\mathrm{R}_{0}=\mathrm{p}(\mathrm{S}) \Pi+[1-\mathrm{p}(\mathrm{S})] \mathrm{L}-\mathrm{w}$. Without some capacity to induce effort firms will only form if the entrepreneur owns enough of the firm.

Consider now the case of monitoring, which we define as gathering verifiable information about effort. If the entrepreneur owns none of the firm, she has no incentive to provide effort even though she is getting paid for it. If the investor does not monitor, the entrepreneur always claims that she exerts the optimal level of effort, whether she does or not, and gets paid $\mathrm{w}$. If the investor monitors, he can block the payment of $\mathrm{w}$ if $\mathrm{p}<\mathrm{p}^{*}$. We assume that the entrepreneur has access to the same verifiable information about effort so that a request for $\mathrm{w}$ cannot be blocked if $\mathrm{p}^{\mathrm{n}} \mathrm{p}^{*}$. The investor bears a fixed cost of monitoring, $\mathrm{c}_{\mathrm{m}}$, that does not depend on his or the entrepreneur's ownership stake. Because in the types of small and medium size firms we have in mind the investor is knowledgeable about the business, monitoring is cheap and has only a small effect on profits. Nonetheless, the investor will only monitor when he owns enough of the firm to make it worth his while. In our model, moreover, monitoring can only occur when the investor exercises control because he must have access to the books of the firm on a timely basis as well as the ability to inspect its operations. The firm's return when there is monitoring, $\mathrm{R}_{\mathrm{m}}=\mathrm{p}^{*} \Pi+\left[1-\mathrm{p}^{*}\right] \mathrm{L}-\mathrm{W}-\mathrm{c}_{\mathrm{m}}>1+\mathrm{r}$.

Definition: Let $S_{m}$ be the value of $S$ such that $R^{*}-c_{m} /[1-S]=R_{0}(S)$.

If the investor monitors he earns $[1-S] R^{*}-c_{m}$. If he does not, he earns $[1-S] R_{0}(S) . R^{*}$ is a constant. $R_{0}(S)+c_{m} /[1-S]$ is increasing in $S$ and is greater than $R^{*}$ for $S \approx 1$ and less than $R^{*}$ for $\mathrm{S}=0$. Hence there is a unique $\mathrm{S}_{\mathrm{m}}$ such that $\mathrm{R}^{*}-\mathrm{c}_{\mathrm{m}} /\left[1-\mathrm{S}_{\mathrm{m}}\right]=\mathrm{R}_{0}\left(\mathrm{~S}_{\mathrm{m}}\right)$. At $\mathrm{S}=\mathrm{S}_{\mathrm{m}}$, the investor is

$\mathrm{p}(\mathrm{E})] \mathrm{L}],-\mathrm{E})$. Her optimal effort, given her equity stake $\mathrm{S}$, requires $\mathrm{S}[\partial \mathrm{U} / \partial \mathrm{Y}][\partial \mathrm{p} / \partial \mathrm{E}][\Pi-\mathrm{L}]-\partial \mathrm{U} / \partial \mathrm{E}=0$. Optimal effort is clearly increasing in S. If S is 0 , effort is nil, and we assume the project fails for sure. 
indifferent between monitoring and not monitoring. If $\mathrm{c}_{\mathrm{m}}$ is small enough, as we assume to be the case, $S_{m}>1 / 2$.

Proposition 1: If shirking is the only problem, profits are higher in a partnership than in a corporation for $\mathrm{S}$ between $1 / 2$ and $\mathrm{S}_{\mathrm{m}}$. For all other equity stakes, profits are the same in both organizational forms. (See Table 1.)

Monitoring occurs when two conditions are met: the investor finds it profitable; and he has adequate control. For $\mathrm{S}<1 / 2$, the investor wants to monitor and has control (in a corporation because he is the majority shareholder and in a partnership because he is joint owner). For $\mathrm{S}$ between $1 / 2$ and $S_{m}$, monitoring is profitable for the investor. Joint ownership allows him to do so in a partnership, but in a corporation he is the minority shareholder and does not have the control needed to monitor. For $\mathrm{S}>\mathrm{S}_{\mathrm{m}}$ the investor does not want to monitor, and both forms lead to the same outcome. As Figure 1 illustrates, if shirking were the only problem, there is no range of equity stakes for which the corporation is superior to the partnership, whereas the partnership is superior for $1 / 2<\mathrm{S}<\mathrm{S}_{\mathrm{m}}$. This conclusion stands a good deal of its literature on its head. Because most economists view joint ownership strictly from the point of view of income rights, they conclude that the partnership inevitably creates a tragedy of the commons. We focus on control rights and show that joint control enables partnerships to solve problems that corporations cannot.

\section{III.A.2. Untimely dissolution}

The value of the corporation is apparent, however, when we consider the problem of untimely dissolution. As noted in Section II, this problem afflicts partnerships but not 
corporations (or more precisely it affects partnerships far more severely than corporations). ${ }^{7} \mathrm{We}$ model untimely dissolution in the following simple way: During the life of a partnership a dispute among the partners may arise that, if the firm is successful, will force its dissolution, and if the firm is not successful, will add to its liquidation costs. We assume that the firm's expected return is reduced by a given fraction $d$. Again, this is a reduced form assumption; $d$ could be large either because disputes are very costly or because they occur very frequently. Unlike in Section III.A.1, effort is contractible, so $\mathrm{p}=\mathrm{p}^{*}$, and there is no need for monitoring.

Proposition 2: If untimely dissolution is the only problem, only corporations are organized. (See Table 2.)

Partnerships earn $\mathrm{R}_{\mathrm{p}}=\left[\mathrm{p}^{*} \Pi+\left[1-\mathrm{p}^{*}\right] \mathrm{L}-\mathrm{w}\right][1-\mathrm{d}]$ or $[1-\mathrm{d}] \mathrm{R}^{*}$. Corporations earn $\mathrm{R}_{\mathrm{c}}=\mathrm{R}^{*}$. Clearly $\mathrm{R}_{\mathrm{p}}<\mathrm{R}_{\mathrm{c}}$.

\section{III.A.3. Minority Oppression}

As we noted in Section II, the control with which corporations endow dominant stakeholders enables them to shift the flow of the firm's revenue stream in their favor-that is, they can extract private benefits. In our simple model with two stakeholders whoever has the majority of shares controls the firm. ${ }^{8}$ We assume that he or she can legally appropriate a fraction $\omega$ of the returns from successful projects and of the assets from failed ones, and that if

\footnotetext{
${ }^{7}$ In our model untimely dissolution serves as a proxy for all losses in earnings associated with joint control. Clearly problems of untimely dissolution will increase with the number of partners; hence it is not surprising that few ordinary partnerships ever involve more than four partners.

${ }^{8}$ Problems of minority oppression might be alleviated if there are more than two stockholders, none of which has an outright majority. For example, if management has only a minority of the shares, then the other stockholders can credibly threaten to remove it should if oppression occur. It is also possible, however, that some stockholders will be tempted to join management and share in the spoils of private extraction. Moreover, as the number of shareholders increases, owners face a collective action problem in limiting private extraction.
} 
appropriation occurs, it is socially inefficient. ${ }^{9}$ A fraction $\beta$ of the firm's return is wasted, leaving $(1-\beta-\omega)$ to be distributed among the shareholders. Effort is contractible $\left(\mathrm{p}=\mathrm{p}^{*}\right)$, and there is no untimely dissolution $(\mathrm{d}=0)$.

If the firm organizes as a partnership, there is no possibility of appropriation because of joint control. Hence $\mathrm{R}_{\mathrm{p}}=\mathrm{p}^{*} \Pi+\left[1-\mathrm{p}^{*}\right] \mathrm{L}-\mathrm{w}$. In a corporation, however, returns depend on whether there is appropriation or not. Whether the controlling stockholder steals depends on the distribution of equity.

Definition: Let $\mathrm{S}_{\mathrm{ca}}$ be the equity stake such that the entrepreneur wants to extract private benefits only if her stake is less than $S_{c a}$. It is easy to show that $S_{c a}=\max \{\omega /[\beta+\omega], 1 / 2\}$. By symmetry, if the investor owns less than $\mathrm{S}_{\mathrm{ca}}$, he will want to extract private benefits.

It follows that if $1-S_{c a}<S<S_{c a}$, then $R_{c}=\left[p^{*} \Pi+\left[1-p^{*}\right] L-w\right][1-\beta]$, the return to the controlling stockholder who owns $\mathrm{S}$ of the firm is $\mathrm{SR}^{*}[1-\beta-\omega]+\mathrm{R}^{*} \omega$, and that to the minority shareholder is $(1-S) R^{*}[1-\beta-\omega]$.

Proposition 3: If minority oppression is the only problem, corporations and partnerships have the same return if one or the other party owns at least $\mathrm{S}_{\mathrm{ca}}$. If neither party owns $\mathrm{S}_{\mathrm{ca}}$, then partnerships are strictly preferred. (See Table 3.)

\section{III.A.4. Single transaction cost theories reconsidered.}

In each of preceding cases involving a single transaction cost, one organizational form turned out to be at least weakly superior to the other over the entire range of equity stakes, though which form was superior depended on whether the problem was shirking, untimely

\footnotetext{
${ }^{9}$ For a discussion of the extent to which appropriation was likely to be found legal by U.S. courts, see Lamoreaux
} 
dissolution, or minority oppression. If each firm faced exactly the same transaction cost, then one organizational form might very well prevail throughout the economy. Because most theories of organizational choice were designed to explain the predominance of the corporation in the post World War II era, it is no surprise that they were single transaction-cost theories. It is also no surprise that they focused on untimely dissolution or the cost of joint ownership, rather than on the benefits of joint control or the cost of minority oppression. Our exploration of the effects of different types of transaction costs on organizational choice suggests that greater caution is in order before generalizing about which form is best. For some firms and industries the cost of untimely dissolution is likely to be more serious than the loss from inefficient appropriation, but for other firms and industries appropriation will be the critical problem to avoid. All other things being equal, firms in the former situation will choose to organize as corporations, but firms in the latter will prefer partnerships.

\section{III.B. Shirking, costly dissolution, and private benefits of control together.}

Taking these transaction costs one at a time is somewhat artificial. If a firm faces all three transaction costs, its returns depend on the entrepreneur's choice of organizational form and equity stake. A partnership without monitoring will earn $R_{p 0}=[p(S) \Pi+[1-p(S)] L-w](1-d)$. A partnership with monitoring will earn $\mathrm{R}_{\mathrm{pm}}=\left[\mathrm{p}^{*} \Pi+\left[1-\mathrm{p}^{*}\right] \mathrm{L}-\mathrm{w}\right](1-\mathrm{d})-\mathrm{c}_{\mathrm{m}}$. Again, a unique $\mathrm{S}_{\mathrm{pm}}$ exist such that monitoring occurs only if $\mathrm{S}<\mathrm{S}_{\mathrm{pm}}$. A corporation without monitoring or private extraction will earn $\mathrm{R}_{\mathrm{c} 00}=\mathrm{p}(\mathrm{S}) \Pi+[1-\mathrm{p}(\mathrm{S})] \mathrm{L}-\mathrm{w}$; one with monitoring but no extraction will earn $\mathrm{R}_{\mathrm{cm} 0}=\mathrm{p}^{*} \Pi+\left[1-\mathrm{p}^{*}\right] \mathrm{L}-\mathrm{w}-\mathrm{c}_{\mathrm{m}}$. A corporation without monitoring but with private appropriation will

earn $R_{c 0 a}=[p(S) \Pi+[1-p(S)] L-w](1-\beta)$; one with both will earn $R_{c m a}=\left[p^{*} \Pi+\left[1-p^{*}\right] L-w\right](1-\beta)-c_{m}$.

and Rosenthal 2006. 
Again, the investor can monitor in a corporation only if $S<1 / 2$, and there will be appropriation if $1-\mathrm{S}_{\mathrm{ca}}<\mathrm{S}<\mathrm{S}_{\mathrm{ca}}$.

Proposition 4: The choice of organizational form depends on the relative magnitude of the different transaction costs and on equity stakes. More precisely, we can distinguish three cases.

A. The case (see Table 4) where dissolution costs are less than appropriation costs $(d<\beta)$ :

If $\mathrm{S}<1-\mathrm{S}_{\mathrm{ca}}$, corporations are the most efficient organizational form. They do not suffer from untimely dissolution or from appropriation (because the investor, who is in control, owns so much of the firm that he would lose more from the decline in its aggregate return than he would gain from appropriation). The investor also monitors, so the entrepreneur exerts the efficient level of effort.

If $1-\mathrm{S}_{\mathrm{ca}}<\mathrm{S}<\mathrm{S}_{\mathrm{ca}}$, partnerships prevail. The losses from appropriation in a corporation are larger than the losses from untimely dissolution in a partnership. The investor can monitor in a partnership over the same range of equity stakes where he can monitor in a corporation. And he can also monitor in a partnership for equity stakes between $1 / 2$ and $\mathrm{S}_{\mathrm{pm}} \cdot{ }^{10}$

If $\mathrm{S}>\mathrm{S}_{\mathrm{ca}}$, corporations are superior to partnerships. There is no untimely dissolution, and there is no appropriation (because now the entrepreneur owns enough of the firm not to want to steal). There is no monitoring, and effort reflects the entrepreneur's stake.

B. The case (see Table 5) where dissolution costs are greater than appropriation costs $(d \geq \beta)$ and the value of monitoring is high (that is, $[1-\beta] \mathrm{R}_{\mathrm{c} 0 \mathrm{a}}(1 / 2)<[1-\mathrm{d}] \mathrm{R}^{*}-\mathrm{c}_{\mathrm{m}}$ ):

As in Case $\mathrm{A}$, if $\mathrm{S} \leq 1-\mathrm{S}_{\mathrm{ca}}$ or $\mathrm{S} \geq \mathrm{S}_{\mathrm{ca}}$, corporations are the most efficient organization. If $1-\mathrm{S}_{\mathrm{ca}}<\mathrm{S} \leq 1 / 2$, corporations still prevail because $\mathrm{d}>\beta$. Because $[1-\beta] \mathrm{R}_{\mathrm{c} 0 \mathrm{a}}(1 / 2)<[1-\mathrm{d}] \mathrm{R}^{*}$, there

\footnotetext{
${ }^{10}$ As in section III.A.1, $\mathrm{S}_{\mathrm{pm}}$ is defined as the equity stake of the entrepreneur such that the investor is indifferent between monitoring in a partnership and not monitoring in a corporation.
} 
exists an S' such that the return to a partnership with monitoring is equal to that of a corporation without monitoring $\left(\mathrm{R}_{\mathrm{pm}}(\mathrm{S})=\mathrm{R}_{\mathrm{coa}}(\mathrm{S})\right)$. Hence if $\mathrm{S}$ is between $1 / 2$ and $\mathrm{S}$, , partnerships will prevail because monitoring is sufficiently valuable to offset the costs of dissolution. If $\mathrm{S}^{\prime} \leq \mathrm{S}<\mathrm{S}_{\mathrm{ca}}$, corporations prevail. Because the entrepreneur now owns a large stake, the value of monitoring is low enough that it does not offset the higher cost of dissolution relative to appropriation.

C. The case (see Table 6) where dissolution costs are greater than or equal to appropriation costs $(d \geq \beta)$ and the value of monitoring is low $\left([1-\beta] R_{c 0 a}(1 / 2) \geq[1-d] R^{*}-c_{m}\right)$ :

Corporations will prevail over the entire range of equity states. For $\mathrm{S}<1 / 2$ and $\mathrm{S}>\mathrm{S}_{\mathrm{pm}}$, the argument is the same as in Case B. For $\mathrm{S}$ between $1 / 2$ and $\mathrm{S}_{\mathrm{pm}}$ the monitoring option offered by partnership is insufficient to offset the high cost of dissolution, and corporations are preferred.

Discussion: When monitoring is valuable or dissolution is not too costly a problem relative to appropriation, partnerships are more desirable than corporations; otherwise the reverse is the case. The two forms of organization, in other words, are complements. To be sure, any given firm has to choose to be either a corporation or a partnership, and thus in that sense the two forms can be seen as substitutes. At the level of the economy, however, the forms are clearly complements if governance problems (rather than relative tax rates or other policy variables) drive organizational choice. That is, to the extent that the transaction costs we have highlighted vary across firms, both partnerships and corporations will prevail in equilibrium. Furthermore, if firms face identical transaction costs but have different distributions of equity, they may very well choose different organizational forms. We have not, we must stress, obtained these results by constructing the model in a way unfavorable to corporations. To the contrary, by assuming that monitoring costs and the probability of untimely dissolution are not related to equity states but that the likelihood of appropriation is, we have given corporations a hidden advantage. 
Finally, it is important to note that, given our assumption that equity stakes are exogenous, there are circumstances under which the entrepreneur may maximize her returns by choosing a suboptimal organizational form. Consider the case where the entrepreneur's equity stake is near fifty percent. If she owns slightly more than half the firm, she may prefer a corporation even if dissolution is much less costly than appropriation $(d<\beta)$, because she will secure private benefits of control only if the firm is organized as a corporation. On the other hand, if her equity stake is slightly below a half, she may prefer a partnership even if $d>\beta$, because in a corporation the investor will have control and will be able to appropriate some of firm's return.

\section{III.C. Endogenous equity stakes.}

We now check the generality of our findings by relaxing the assumption that equity stakes are exogenous. We shift the focus of attention back to the first period, when the entrepreneur acquires the capital she needs to realize her idea, and make two further assumptions: (1) that the joint wealth of the entrepreneur and the investor exactly equals the capital required for the entrepreneur's project $\left(\mathrm{W}_{\mathrm{e}}+\mathrm{W}_{\mathrm{i}}=1\right)$; and (2) that the entrepreneur makes a take it or leave offer to the investor that includes both the firm's organizational form and the distribution of its equity.

One can show that equilibria always exist, though they may involve the firm not forming. One can also show that they are generically unique. ${ }^{11}$ Fully characterizing the equilibria is tedious because they depend on the absolute value of parameters such as $\Pi$ and $\mathrm{L}$ and also on the

\footnotetext{
${ }^{11}$ Multiple equilibria arise when $\mathrm{d}=\beta$. For $\mathrm{d} \neq \beta$ they arise for at most three discrete values of $\mathrm{W}_{\mathrm{e}}$. In these cases the entrepreneur may be indifferent between the partnership and corporate forms or between two different equity stakes within an organizational form. We break all ties in favor of corporations.
} 
relative values of others like $d$ and $\beta$. Instead, we offer five propositions that highlight the most interesting results. $^{12}$ The first three propositions detail the most important new insights we gain from allowing equity stakes to be endogenous. They show that transaction costs affect less profitable firms more than profitable ones, and that transaction costs can significantly reduce entry when wealth constraints bind. The last two propositions demonstrate that the key results from the analysis of exogenous stakes still hold for the endogenous case: partnerships and corporations are complements; and the transaction costs faced by the firm together with the wealth of the associates jointly determine how the firm is organized.

Proposition 5: Firms with very high or very low returns have the fewest governance problems.

When profits are high enough, the entrepreneur can secure the investor's capital by offering him a sufficiently tiny stake that the firm operates as if it were a sole proprietorship. When profits are very low, the only firms that form are those where one of the two parties contributes nearly all the capital and is effectively the sole owner. Firms with more even distributions of investment cannot form because the participation constraints cannot be satisfied.

Proposition 6: Some equity stakes are never offered in equilibrium, in particular those that are slightly larger than $1-\mathrm{S}_{\mathrm{ca}}, 1 / 2$, and $\mathrm{S}_{\mathrm{pm}}$, as well as those that are slightly smaller than $\mathrm{S}_{\mathrm{ca}}$

If equity stakes only determined income flows, then the entrepreneur would simply offer the investor the smallest stake that secured his participation. However, equity stakes also affect both control rights in corporations and the inventor's incentive to monitor regardless of organizational form. As a result, the entrepreneur does not always minimize the investor's stake, because doing so may change control rights and the investor's incentives in ways that adversely

\footnotetext{
${ }^{12}$ The proofs of the propositions are of limited technical interest and thus have been relegated to the appendix.
} 
affect the aggregate return of the firm. Consider the case where the investor could afford a stake $S_{c a}$. Then firm's return would $R^{*}-c_{m}$. To buy $S_{c a}$ the investor must have wealth $W_{i}=\left[S_{c a}\left[R^{*}\right]-\right.$ $\left.\mathrm{c}_{\mathrm{m}}\right] /[1+\mathrm{r}]$. Now suppose $\mathrm{W}_{\mathrm{i}}$ is slightly less than $\left[\mathrm{S}_{\mathrm{ca}}\left[\mathrm{R}^{*}\right]-\mathrm{c}_{\mathrm{m}}\right] /[1+\mathrm{r}]$. If the investor gets a stake that is slightly less than $\mathrm{S}_{\mathrm{ca}}$, he will want to appropriate. His return will jump up, and the firm's return will jump down. Both those movements imply that the entrepreneur's return falls discretely. She is better off keeping the investor's stake at $\mathrm{S}_{\mathrm{ca}}$, even though he cannot quite afford to pay her $\left[\mathrm{S}_{\mathrm{ca}}\left[\mathrm{R}^{*}\right]-\mathrm{c}_{\mathrm{m}}\right] /[1+\mathrm{r}]$. More generally, the function that maps equity stakes into the entrepreneur's returns has discrete jumps at $\left(1-\mathrm{S}_{\mathrm{ca}}\right), 1 / 2, \mathrm{~S}_{\mathrm{pm}}$, and $\mathrm{S}_{\mathrm{ca}}$, introducing flat spots into the equilibrium relationship between investor wealth and investor equity stakes. At the right edge of a flat spot there will be a discontinuous increase in the entrepreneur's equity stake, leaving a gap in the observed distribution of equity stakes.

Proposition 7: As $d$ and $\beta$ increase, firms with relatively equal investment stakes are less likely to form.

Firms bear few transaction costs if either the entrepreneur or the investor owns almost all the firm. For firms where the entrepreneur must sell more than $1-\mathrm{S}_{\mathrm{ca}}$ but the investor cannot afford $\mathrm{S}_{\mathrm{ca}}$, aggregate returns will be reduced by either a dissolution cost or an appropriation cost. Firms will earn strictly less than the max of $\left\{[1-d] R^{*},[1-\beta] R^{*}\right\}$. If $R^{*}$ is close enough to $1+r$, the aggregate participation constraint will bind, and it is more likely to do so as $d$ or $\beta$ increases. In any case so long as the distributions of $d$ and $\beta$ across firms are not too closely correlated, for some firms participation constraints are likely to bind in corporations but not in partnerships whereas for other firms the situation will be just the reverse. As a result, low-profit firms are likely to be a mix of corporations and partnerships. 
Proposition 8: If $\Pi$ is small enough, for two intervals of the entrepreneur's wealth, $\left\{1, \mathrm{~W}_{\mathrm{e} 1}\right\}$ and $\left\{\mathrm{W}_{\mathrm{e} 2}, 0\right\}$, the firm organizes as a corporation. For wealth between $\mathrm{W}_{\mathrm{e} 1}$ and $\mathrm{W}_{\mathrm{e} 2}$ the firm does not form. As $\Pi$ increases, the range where the firm does not form shrinks and ultimately disappears. Instead, there will be a middle range of the entrepreneur's wealth such that the firm is organized as a partnership. As $\Pi$ increases further, the lower range of wealth where the firm organizes as a corporation will disappear, and as $\Pi$ continues to increase, the range at which it organizes as a partnership will also disappear. If $\Pi$ is large enough, the firm operates as a corporation under the entrepreneur's control whatever her initial wealth endowment.

If $\Pi$ is sufficiently close to $1+r$, the firm cannot bear any significant transaction costs if it is to meet the associates' participation constraints. Hence it can only operate if it can be a quasisole proprietorship $\left(\mathrm{S}>\mathrm{S}_{\mathrm{ca}}\right.$, or $\left.\mathrm{S}<1-\mathrm{S}_{\mathrm{ca}}\right)$. As $\Pi$ rises, some firms with more even divisions of equity will be able to form. Let $\mathrm{W}_{\mathrm{el}}$ be the level of entrepreneurial wealth such that the firm forms if the entrepreneur invests at least $\mathrm{W}_{\mathrm{e} 1}$ but does not form if she invests less. Symmetrically, $\mathrm{W}_{\mathrm{e} 2}$ is the level of entrepreneurial wealth such that the firm forms only if the entrepreneur invests less than $\mathrm{W}_{\mathrm{e} 2}$. By definition, at $\mathrm{W}_{\mathrm{e} 1}$ and $\mathrm{W}_{\mathrm{e} 2}$ the return to the firm is exactly $1+\mathrm{r}$. The second part of the proposition simply says that $\mathrm{W}_{\mathrm{e} 1}$ is decreasing in $\Pi$, except where the return function has jumps. Consider the case where, at $\mathrm{W}_{\mathrm{e} 1}$, the firm is run as a corporation without monitoring. When $\Pi$ increases, $R(S)$ must increase for every $S$. That means that the entrepreneur can sell a little bit more of the firm while maintaining the same return on capital. Hence $\mathrm{W}_{\mathrm{e} 1}$ falls.

Now let us consider the effect of relaxing the assumption that $\mathrm{W}_{\mathrm{e}}+\mathrm{W}_{\mathrm{i}}=1$. We do not fully eliminate the wealth constraint, however. That is, we do not allow $W_{\mathrm{e}} \geq 1$ or $\mathrm{W}_{\mathrm{i}} \geq \mathrm{R}^{*} /(1+\mathrm{r})$ because in those cases either the entrepreneur or the investor could assume sole ownership. 
Proposition 9: The first best outcome $\left(\mathrm{R}=\mathrm{R}^{*}\right)$ cannot only be reached if wealth constraints are fully relaxed. When the first best cannot be reached, the firm will be either a partnership or a corporation depending on the relative intensity of the various transaction costs and the relative wealth of the two associates. Holding one associate's wealth constant, aggregate returns are weakly increasing in the wealth of the other.

As Proposition 9 suggests, one has to eliminate wealth constraints to make governance questions irrelevant to the profitability of the firm. Nevertheless, as the associates' wealth increases, the entrepreneur gains greater flexibility in organizing the firm. She uses that increased flexibility to avoid those equity distributions that have the worst transaction costs.

Making equity stakes endogenous does not dramatically alter the previous section's conclusion that partnerships and corporations are, from the standpoint of the economy, complementary organizational forms. If the entrepreneur is the residual claimant, she finds that corporations are valuable under a number of circumstances (for example, when investment stakes are relatively extreme or when firms have very high profits), but partnerships are better for firms with relatively even investment stakes and with intermediate levels of profits. In our model all but the most profitable firms suffer from either shirking or monitoring costs and either dissolution or appropriation costs. Having access to more than one organizational form allows the associates to reduce the burden of such costs.

\section{The Model, the Law and U.S Enterprises, 1850-1950}

For the model to capture the essential features of the U.S. legal rules during the late nineteenth and early twentieth centuries, the following assumptions must hold: (1) business people have access to only two alternative organizational forms, partnerships and corporations; 
(2) disputes among members of a firm can lead to untimely dissolution in partnerships, but not in corporations; (3) majority shareholders are dictators and can adversely affect the interests of minority owners in corporations, but not in partnerships; and (4) side contracts that mitigate disputes in partnerships and minority oppression in corporations are unimportant or unenforceable.

The first assumption fits the U.S. case well. Although the partnership form crossed the Atlantic with the first settlers, incorporation initially required government permission in the form of a special legislative act. During the early nineteenth century several of the most industrial states made corporate charters increasingly easy to obtain and, around mid-century, most states routinized the process by passing general incorporation laws (Evans 1948; Hurst 1970; Maier 1993; Blair 2003). Although most states passed legislation during the 1820s and 1830s permitting businesses to adopt a third organizational form, the limited partnership, the statutes were so restrictive and the courts so conservative in interpreting them that few firms exploited the option (Lamoreaux and Rosenthal 2005; see also Lewis 1917; Warren 1929; Howard 1934). ${ }^{13}$

The second assumption, that partnerships suffered from untimely dissolution but corporations did not, also finds support in U.S. law. Under the common law partnerships were not legal persons. They had no identity independent of the specific individuals who formed them and, in effect, existed only at the will of the members. Associates could exit from firms and force them to dissolve whenever they thought that their partners had proved untrustworthy or were pursuing business strategies that seemed ill advised. Corporations, by contrast, were legal persons and were in no way dependent on the existence or ongoing participation of the people

\footnotetext{
${ }^{13}$ A small number of states also passed enabling legislation during the 1870s and 1880s for a precursor of the limited liability company called the partnership association, but this form was also little used (Warren 1929; Stransky 1956; Schwartz 1965; Gazur and Goff 1991).
} 
who founded them. They could only be dissolved by a majority vote of their stockholders (Lamoreaux and Rosenthal 2006).

The third assumption captures differences between corporations and partnerships in terms of owners' capacity to intervene in their firms' affairs. Any and all members of a partnership could act in its name, whereas only officers elected by stockholders could encumber a corporation or allocate its resources (Freund 1896). In the U.S., both statute and practice quickly converged to a standard one-vote-per-share, majority-rule governance structure for corporations that made shareholders who possessed enough stock to decide elections effectively dictators (Dunlavy 2004). Although this governance structure prevented disagreements among stockholders from hobbling the firm or subjecting it to untimely dissolution, it also potentially subjected minority shareholders to exploitation. There were a variety of ways in which controlling shareholders could use their power to tilt the firm's revenue stream in their direction. Among the most common techniques were electing themselves to corporate offices and then voting themselves high salaries or negotiating lucrative contracts with other firms in which they had an interest. In the absence of egregious fraud, the courts were reluctant to intervene and put a stop to such practices. ${ }^{14}$

One might assume that, in a common law country like the U.S., the flaws of both the partnership and corporate forms would be relatively easy to remedy by means of side contracts. Business people did try, but the contracts they drafted often proved difficult to enforce. Hence the fourth assumption is a reasonable approximation as well. Take, for example, the problem of untimely dissolution in partnerships. Although partners could contract in advance not to dissolve the firm before the expiration of a specified period of time, the courts were extremely reluctant to 
enforce such agreements when disputes arose among the partners. Indeed, some courts worried that restrictions on dissolution might themselves be pernicious and went so far as to declare that the right to dissolve a partnership at will could not be contracted away. ${ }^{15}$ At the same time, agreements that reduced the likelihood of disputes were also often unenforceable. For example, although partners could and often did sign agreements that restricted the ability of one or more of their number to contract debts on behalf of the firm, these arrangements were not legally binding with respect to third parties who had not been given formal notice of their terms. Although a partner might seek an injunction in equity against a member of the firm who violated such an agreement, this remedy could do little more than force the dissolution of the firm (Story 1859; Warren 1929).

Contracting around the fundamental features of the corporate form was equally difficult. Members of corporations might attempt to use shareholders' agreements to protect themselves against the tyranny of the majority, but these contracts often turned out to be unenforceable. For example, there was a high probability that agreements that required shareholders' unanimity (or even a super-majority vote) for corporate decisions would be overturned by the courts (Hornstein 1950 and 1953; Cary 1953; O’Neil 1953, 1958, and 1965; Gower 1956). Even worse, shareholders who entered into such agreements risked being held partners and thus unlimitedly liable for their firms' debts. ${ }^{16}$ Although the courts would not permit stockholders to opt out of the standard corporate governance rules, they did allow them to contract among themselves to exercise their votes in particular ways. For example, the courts were usually willing to enforce

\footnotetext{
${ }^{14}$ See, for examples, Hodges v. New England Screw Company, 1 R.I. 312 (1850); Faud v. Yates, 57 Ill. 416 (1870); Hawes v. Oakland, 104 U.S. 450 (1881); Dunphy v. Traveller Newspaper Association, 146 Mass. 495 (1888); Burden v. Burden, 159 N.Y. 287 (1899). For a discussion of this case law, see Lamoreaux and Rosenthal 2006. ${ }^{15}$ Solomon v. Kirkwood, 55 Mich. 256 (1884), citing Skinner v. Dayton, 19 Johns. 513 (N.Y. 1822). Partners that sought unilaterally to dissolve a partnership before its term was up might be subject to damages, but disputes among the partners were always grounds for dissolution. See Lamoreaux and Rosenthal 2006.
} 
agreements among stockholders to vote for particular persons as directors or to place their stock in voting trusts whose officers in turn would choose the directors of the firm. The problem, however, was that such agreements could actually worsen the situation of minority shareholders by making it easier for a controlling group to solidify its power. ${ }^{17}$

That the four basic assumptions of our model reasonably capture the organizational choices that U.S. business people faced in the late nineteenth and early twentieth centuries is not surprising because we built the model with the U.S. legal rules in mind. We now turn to the 1900 U.S. Census of Manufactures, the first to provide data on organizational form, to explore the fit of our model to the empirical evidence. In particular, we use Census data to test the main implication of our model - that partnerships and corporations are complementary forms of organization - against the view championed by Alchian and Demsetz and Hart that corporations are superior substitutes for partnerships. If the latter scholars are correct, we should expect the distribution of organizational forms to be driven largely by technological factors that affect the magnitude of the non-contractible problems that incorporation resolves. For example, we should find capital intensive industries and those characterized by economies of scale to be dominated by corporations. More generally, we should find industries with large numbers of corporations to have very few partnerships and vice versa.

The manuscript Census returns have been lost, so we analyze the distribution of corporations and partnerships at the most disaggregated level possible: 322 individual industries broken down by state and territorial units, yielding about 4,700 industry-state observations with

\footnotetext{
${ }^{16}$ See, for example, Vandyke v. Brown 4 Halstead 657 (1852); Jackson v. Hooper, 76 N.J. Eq. 592 (1910); and Benintendi v. Kenton Hotel, 294 N.Y. 118 (1945).

${ }^{17}$ See, for example, Brown v. Pacific Mail Steamship Co., 5 Blatchf. 525 (1867); and Faulds v. Yates, 57 Ill. 416 (1870). Even when such contracts were employed by the minority to protect their interests, there were limits to what they could achieve. Most importantly, they could not be used to bind the directors to pursue a particular set of policies or elect specific people as officers. See, for examples, Guernsey v. Cook, 120 Mass. 501 (1876); Cone v. Russell, N.J. Eq. 208 (1891); and Manson v. Curtis, 223 N.Y. 313 (1918).
} 
at least one multi-owner firm. Table 7 reports the results of various OLS regressions of capital and labor per establishment on the share of partnerships among multi-owner firms, some of which include fixed effects for states and/or industries. It also reports the same analysis as Tobit regressions because the share of partnerships is censored both at 0 and at 1 . The results are qualitatively similar. $^{18}$

The regressions provide some support for the conventional view that partnerships and corporations were substitutes. In additional (unreported) OLS specifications, industry fixed effects alone explain a large amount (47 percent) of the total variation in the share of multiowner firms that were partnerships. State fixed effects are statistically significant, but they explain only a small part (less than 7 percent) of the variance. Capital per establishment and employment per establishment together explain some 36 percent of the variance. Of course, the scale variables and the industry fixed effects have an important common component. Considered all together, these sets of variables can explain some 60 percent of the total variation in the share of multi-owner firms that were partnerships. ${ }^{19}$

Nevertheless, if we consider the implications of the coefficients reported in Table 7, the news is not all good for the substitutes view. Column 9 (the most favorable to that perspective) reports a coefficient of -0.14 for the $\log$ of capital. Note that the mean share of multi-owner firms across all industry-state branches that were partnerships was 61 percent and the standard deviation of the log of capital was 1.76. If one moves from branches where capital per

\footnotetext{
${ }^{18}$ The Tobit regressions failed to converge with fixed effects for state and industry, so we instead used fixed effects for region and sector (as defined by the census). The results are similar but the sector fixed effects obviously absorb less of the variance than the industry fixed effects.

${ }^{19}$ Additional regressions using value added per establishment or capital per worker confirm that industries that were capital intensive or operated at a large scale had more corporations. We also performed (again with similar results) the same analysis using state-industry aggregates (for example, total capital in iron and steel in Iowa). Because establishment size is partly given by technology (which is deployed at the establishment level) and partly the result of the magnitude of demand (which operates at a more aggregate level) one could argue in favor of either specification.
} 
establishment was around the mean to those where it was at least one standard deviation higher, the share of partnerships falls to 36 percent. At two standard deviations from the mean, it falls to 11 percent. Although these are large reductions in the share of partnerships, partnerships remained popular until average capital per establishment became quite large.

If the substitutes view is correct, one might also expect corporations to be relatively more prevalent in the more advanced parts of the economy. We define the manufacturing belt to include the band of states in southern New England, the northern Middle Atlantic, and the East North Central regions that are conventionally viewed as the main manufacturing centers during this period. When we include in the regressions an interaction term between a dummy for the manufacturing belt and capital per establishment (see specifications 5 and 8 in Table 7), the estimated coefficient is positive, suggesting that in the U.S. manufacturing heartland partnerships were actually slightly more popular than elsewhere. More precisely, firms in industry cells with larger average establishment sizes were more likely to be partnerships within the manufacturing belt than in other parts of the country.

The persistence of partnerships in state-industry branches with large establishments, particularly in the manufacturing belt, is problematic for the substitutes hypothesis, but the aggregate data offers even stronger evidence against this view (see Table 8). Consider the 322 industries enumerated by the Census, and define an industry to be dominated by a single organizational form if 90 percent of its multi-owner firms are either partnerships or corporations. Such industries accounted for 22 percent of the capital in manufacturing, 19.5 percent of employment, and 24 percent of value added. ${ }^{20}$ By contrast, industries where both forms were

\footnotetext{
${ }^{20}$ Giving a very liberal interpretation to "dominant," and taking an industry to be dominated by a form if 80 percent of all multi-owner firms were of one or the other type, expands the figures to 47 percent of capital, 57.5 percent of employment and 48 percent of value added, with most of the increase coming from including more industries with a high proportion of partnerships.
} 
well represented (with corporations and partnerships each being at least 25 percent of multiowner firms) accounted for nearly half of all capital, labor, and output. Interestingly enough, fully 57 percent of all manufacturing corporations were located in industries where both forms were abundant. At the industry level, the view that the two organizational forms were complements is difficult to escape. Moreover, repeating this exercise with state-industry cells yields very similar results.

Over the course of the twentieth century the number of corporations would rise relative to partnerships, so that by the end of the century there were more than 2.5 corporations for every partnership in the economy as a whole and more than 8 corporations for every partnership in the manufacturing sector (Carter et al. 2006). Much of this change owed to tax policy during the forty years following World War II. Corporations paid a flat tax rate on their income that ranged from a post-World War II peak of 52 percent to a low of 46 percent on the eve of the Tax Reform Act of 1986. Partnership income was subject to the personal income tax, and rates for the top brackets were higher than the corporate level (often substantially) before the 1980s. In addition, whereas the flat corporate tax rate was not affected by inflation, the progressive personal income tax subjected individual tax payers to bracket creep, forcing marginal rates relatively higher. These and other differences raised the burden of personal relative to corporate taxes during this period, encouraging firms to organize as corporations (Brownlee 1996). ${ }^{21}$

\footnotetext{
${ }^{21}$ Of course, corporate dividends were also taxed as personal income, but in closely held corporations there were many ways to avoid double taxation. Some idea of the magnitude of the incentive can be seen from the following comparison: In 1950 the amount of revenue raised by the corporate and personal income taxes was about the same; by 1980 the personal income tax yielded four times the revenue of the corporate tax. Legislation during Ronald Reagan's presidency reversed this situation, first by reducing the top personal tax rate to 50 percent in 1981, and then, with the Tax Reform Act of 1986, by reducing it to 28 percent (the 1986 Act also dropped the corporate rate from 46 to 34 percent). The impact of these changes on business people's organizational choices was to a large extent counteracted, however, by legislation liberalizing the rules under which small corporations could claim Subchapter S status, which essentially allowed them to be taxed as partnerships. Especially after the 1986 Act, growing numbers of firms filed as s-corporations, but there was comparatively little shifting from the corporate back to the partnership form. In the meantime, most states had passed legislation increasing the ability of members of
} 
The uneven magnitude of the shift toward corporations across the economy (see Carter et al. 2006, Tables Ch1-192) suggests, however, that there were also underlying economic reasons for the relative decline of partnerships. Looking only at the manufacturing sector, corporations accounted for 14 percent of all establishments in 1900, 53 percent of employment, and 65 percent of output. By the eve of the Great Depression, when the 1929 Census of Manufactures was taken, the share of corporations had risen to 48 percent of establishments, 89 percent of employment, and 92 percent of output. Much of the change can be accounted for by the rising scale of enterprise. The average size of corporations increased very little (from 75 workers per establishment in 1905 to 78 in 1930). Similarly, the average size of non-corporate establishments remained essentially the same at 9 workers per establishment in 1905 and 8 in 1929. What changed was the average size of establishments in the sector as a whole, increasing from 19 workers in 1905 to 42 in $1930 .^{22}$ The rising scale of enterprise increasingly tipped the balance toward corporations, but it did not eliminate the trade-off that made partnerships an attractive choice for many SMEs, especially outside the manufacturing sector where the size of establishments was not growing as rapidly.

\section{The Model, the Law, and French Enterprises, 1833-1923}

Two of the four assumptions that our model makes about the legal rules clearly do not fit the French case. The Code de Commerce granted French business people more than two organizational choices. They could form partnerships (nom collectif), limited partnerships (commandite simple), limited partnerships with tradable shares (commandite par actions), and 
(after 1867) corporations (anonymes). Moreover, business people had considerable ability to modify the basic forms to suit their contracting needs. Under the Code, firms had to file summaries (and after 1867 the full text) of their articles of association with the local tribunal of commerce. Because interested parties could obtain copies from the clerk of the court, contracts that conformed to the registration requirements of the Code were fully enforceable (Lamoreaux and Rosenthal 2005). ${ }^{23}$ Nonetheless, French businesses faced organizational tradeoffs that were very similar to those in the U.S., albeit not quite as stark. The contractual flexibility imbedded in the Code enabled business people to mitigate the problems associated with untimely dissolution and private benefits of control but not to eliminate them altogether.

In France, for example, members of partnerships could write enforceable contracts that limited who could act on behalf of the firm, whose signatures were required to borrow, and even whether the firm could incur debts. Presumably, settling these matters in advance reduced the likelihood of disputes compared to a situation in which all of the partners exercised full ownership rights, but it did not eliminate it. Partnerships in France, as in the U.S., were still effectively terminable at will—even those with specified terms (Riviere 1882; Lyon-Caen and Renault 1924, 349). When disputes arose, commercial tribunals attempted arbitration. If the arbiters failed to reconcile the associates, they or the tribunal ordered the partnership dissolved (Ripert 1967, 67; Lyon Caen and Renault 1924, 349-52, 1211). Recontracting at the expiration of a term, moreover, was just likely to lead to disputes, and thus to the untimely dissolution of successful enterprises, as it was in the U.S.

\footnotetext{
${ }^{22}$ U.S. Census Office, Census of Manufactures: 1900, Vol. VII, Table 7, p. 503; Census of Manufactures: 1910, Vol. VIII, Table 1, pp. 136-153; Census of Manufactures: 1920, Vol. VII, Table 25, p. 108; Census of Manufactures: 1930, Vol. I, Table 2, p. 95.

${ }^{23}$ After 1832 firms were also required to publish these summaries in the tribunal's journal. Entrepreneurs in Paris conformed to the new legislation within weeks, but elsewhere publication was spotty. In the twentieth century, the information held by local tribunals was centralized in the "Registre du commerce."
} 
Commandites simples brought together one or more general partners, who managed the firm and were unlimitedly liable for its debts, and one or more silent partners, whose liabilities were limited to their investments and who played no role in management. They were set up for specific terms, and because the silent partners could neither intervene in the affairs of a profitable firm nor terminate their participation before the expiration of the term, the problem of untimely dissolution was less than in an ordinary partnership (Merle 1998; De Juglard and Ippolito 1999; Protection des minoritaires 2001, 140). However, because silent partners could not participate in the firm's management, they were susceptible to exploitation by the general partners. Moreover, relative to general partners, they had only a limited ability to monitor. As a result, except in cases where the entrepreneur's equity stake was a sufficient motivator, limited partnerships were likely to bear more substantial shirking costs than ordinary partnerships.

When commandites simple are compared to partnerships, therefore, the central trade-offs in our model between untimely dissolution and private benefits of control are preserved. They are also preserved when commandites simple are compared to commandites par actions. The latter had all of the trappings of commandites simples with three key additions: the shares of the silent partners were tradable; shareholders could elect audit committees whose responsibility it was to scrutinize the books; and shareholders could require that the managing partners secure support (as well as the approval of major decisions) from a majority of their number at annual meetings of the firm. Although the managing partners bore unlimited liability, it was possible to replace them without dissolving the firm. Hence a silent partner who owned more than half the equity could exercise a great deal of control (Lyon-Cahen and Renault 1924).

Commandites simples were more likely to suffer from untimely dissolution than commandites par actions because the withdrawal of a general partner automatically signaled the 
end of the former whereas in the latter case shareholders could appoint another managing partner. By contrast, silent partners in commandites faced a lower risk of expropriation than minority shareholders in commandites par actions - in part, ironically, because their monitoring options were far more extensive (Riviere 1882,150). An individual holding a small stake in a commandite par actions would have little chance of being appointed to the audit committee. Moreover, small shareholders could be entirely disenfranchised (firms could require, for instance, that shareholders own a minimum number of shares in order to participate in the general meetings). In a commandite simple, however, silent partners were empowered to examine the books, even though they did not participate in management. That access to information, along with the need for periodic recontracting, probably reduced the proportion of a firm's returns that its general partners could appropriate (Merle 1998; Protection des minoritaires 2001, 57).

After a decade of debate, France enacted a general incorporation law in 1867. Because incorporation required both hefty registration fees and a costly notarized contract, it was relatively more expensive to take out a corporate charter in France than in the U.S. But French corporations had offsetting advantages. In particular, it was much easier for their organizers to write enforceable side contracts. For example, French corporations could adopt voting schemes other than the one-vote-per-share, majority-rule standard. Setting supra-majority thresholds for important decisions could reduce the likelihood that minority shareholders would be expropriated, but it could also increase the probability of deadlock. Perhaps for this reason, it seems to have been relatively uncommon for corporations to protect minority shareholders in this way. To the contrary, most deviations from the standard governance rules seem to have had the opposite purpose - to solidify the control of the majority. Instead, the most common technique 
used to reassure minority shareholders was the stipulation of a minimum level of dividend payments. During the mid-nineteenth century provisions mandating that minimum dividends appeared with some frequency in the articles of association. Although these provisions could not prevent majority shareholders from tilting the firm's revenue stream in their direction, they did put limits on the extent of expropriation.

Despite their greater contractual freedom, French businesses faced essentially the same organizational tradeoffs as did firms in the United States. One should observe, therefore, a similar persistence of alternative organizational forms long after general laws made the corporate form readily available. As Figure 2 shows for the case of businesses organized in Paris, the main impact of the 1867 general incorporation law was slowly but surely to eliminate the commandite par actions. Published data for France as a whole show a similar pattern. ${ }^{24}$ Share commandites had accounted for 6 percent of new firm registrations in France from 1840 to 1867, but they fell to 2.5 percent over the next quarter century and then to 1.3 percent between 1894 and 1914 . Corporations and commandites par actions operated under essentially the same rules, except that only in a corporation did all members of the firm enjoy limited liability. Hence the commandite par action was the inferior substitute for the corporation. There was no similar decline in the forms for which the corporation was not such a close substitute: commandites simple and ordinary partnerships. Taken together these latter two types of organization still accounted for 85 percent or more of all firm registrations in France as late as the eve of World War I, nearly a half century after the advent of general incorporation.

There is abundant evidence, moreover, that the major forms of business organization served complementary purposes. Although the French industrial censuses did not report 
information on organizational form, multi-owner firms were required to provide local commercial courts with summaries of their governing statutes. Using the registrations filed with the Paris Tribunal of Commerce, we have constructed a database that provides information on the organizational choices made by individual firms in all sectors of the economy for the period 1833 to $1850 .{ }^{25}$ Because the registration requirements aimed to highlight the firm's legal obligations, the records contain no information about output or numbers of employees, and the information they provide about capital is both imperfect and sporadic. Although these deficiencies limit the kind of statistical analysis we can deploy, the registration data have some significant advantages. They cover all multi-owner firms that registered in Paris, not simply manufacturing enterprises, and we can link the registrations over time. The reader should bear in mind, however, that the French data represent flows of new registrations. Given that partnerships had relatively short life spans (because most changes in their articles of association required firms to dissolve and re-register), these forms tend to be over represented in the data relative to their proportions in the population as a whole.

The distribution of organizational forms by sector of economic activity is reported in Table 9. As in the U.S. a half century later, one can find industries where one organizational form dominated. The most obvious example is retail and wholesale trade, where multi-owner firms were disproportionately organized as partnerships. Because the capital of these firms was invested mostly in relatively liquid inventory, the cost of untimely dissolution was likely to be low. Furthermore, partners tended to work in the same physical space, and so monitoring was both valuable and relatively costless.

\footnotetext{
${ }^{24}$ Annual issues of the Compte général de l'administration de la justice civile et commerciale. Because the published data only begin in 1840, we put together a longer series by focusing on Paris and culling registrations from the pages of the Gazette des tribunaux for 1833 to 1850.
} 
As this example suggests, technology played an important role in determining how firms would be organized - just as it did in the U.S. Take the case of the transportation sector. Railroads all initially organized as commandites par actions, but their contracts stipulated that this arrangement was only a temporary expedient until a charter of incorporation could be obtained. From 1833 to 1850 only one railroad — a spur to the line from Paris to Brusselsactually operated as a share commandite; all the others became corporations. Because railroads invested most of their resources in firm specific assets (only their rolling stock was relatively liquid), incorporation was an important way of preventing costly dissolution. ${ }^{26}$ River transport companies also generally organized as commandites par actions ( 84 percent of them took this form), but their charters did not include plans to convert to corporations. Although their investments in capital equipment were substantial (they were adopting new steamboat technology at this time), riverboats could be sold fairly easily. Hence firms in this subsector did not face costs from untimely dissolution that were as severe as for railroads. By contrast, more than half of all overland transport firms took the form of partnerships, even though at times the number of partners amounted to a dozen or more and the partners were often also members of other firms. Improvement in roads and the consequent growth of traffic had created new business opportunities for carriage companies that could coordinate their schedules over long distances. It was easy to verify whether the other partners kept to schedules and met connections. Moreover, the cost of dissolution was trivial because each party simply reclaimed its own rolling stock.

\footnotetext{
${ }^{25}$ This period, of course, predates general incorporation, but because commandites par actions were close substitutes for corporations, French businesses faced a full menu of organizational forms.

${ }^{26}$ Beyond the governance issue, it is also possible that the scale of operations was such that no one was willing to serve to be an unlimitedly liable partner. Moreover, the Paris bourse closed its doors to the stock and bonds of commandites par actions. These assets could only be traded on the coulisse or 'curb' market.
} 
Although these examples are consistent with the idea that the various organizational forms are substitutes, they are overwhelmed by the evidence for complementarity. Partnerships accounted for less than 25 percent of new registrations in only 12 of 122 economic subsectors, and in only 20 did they account for more than 80 percent. Moreover, the sub-sectors in which partnerships accounted more than four out of five new registrations represented only 12 percent of total registrations. The most common pattern was for firms in each industry to take a variety of organizational forms. New registrations in banking, for example, were nearly evenly divided between each of the three main types of organization: 93 of the firms chose to organize as commandites par actions; 85 as commandites simples; and 101 as partnerships. Although clock and instrument makers preferred partnerships, forming 71 such firms, they also organized 7 commandites par actions and 11 commandites simples. Textile manufacturers formed 50 commandites par actions, 126 commandites simples, and 442 partnerships.

It is, of course, possible that the within industry variation we observe is just an artifact of a poor or overly coarse classification scheme. The U.S. Census divided the manufacturing sector into 322 industries. That breakdown by no means eliminated technological heterogeneity within industry categories, yet we have used only 122 classifications for the entire French economy. However, if technology (or any other industry characteristic) dictated organizational form, one would expect businesses to keep whatever form they initially took, so long as their scale of operation did not change too much. By contrast, our model predicts that the characteristics of the individual owners should also matter for the choice of organizational form. That is, if our model is correct, one should observe firms shifting organizational structure over time as the identity of the owners or the owners' personal characteristics changed. We have identified 1,172 instances in our 1833-1850 database when a business was reorganized (that is, when one legal entity was 
dissolved and replaced by another legal entity, but the business continued to operate). As Table 10 shows, some 389 of these reorganizations ( 31 percent) were associated with changes in organizational form. For example, 97 partnerships became commandites simple and 62 became commandites par actions. Similarly, 94 commandites par actions became partnerships and 38 commandites simples. Closer inspection of the data suggests, moreover, that the changes cannot be ascribed simply to increases or decreases in the fortunes and sizes of these firms.

Take the Marret jewelry firm as an example. It first appears in our data as a partnership formed in 1826 with three partners. In 1829 the senior partner, Claude Bernier, withdrew from active management, and the firm was reorganized as a commandite simple called Marret Frères that continued until 1834. The younger of the two Marret brothers then withdrew, leading to the organization of a new commandite simple with Bernier, still the silent partner, contributing two thirds of the firm's 300,000 franc capital. In 1836 the commandite was dissolved, and the elder Marret operated the business as a sole proprietorship for a decade until he teamed up with two new partners late in 1846 . The firm then had a capital of 600,000 francs, half of which was Marret's. The 1846 articles of association anticipated that Marret would withdraw from the firm in 1856 and that Jarry and Gaime, the other two associates, would continue the firm for another year and a half. Through all these shifts in ownership and organizational form, the core activities of the business remain unchanged. Over these two decades, the firm operated at 16 , rue Vivienne, producing and retailing jewelry with the same technology, and its capital at least doubled. Yet it was a three-person partnership in 1850 just as it had been in the 1820 s. Neither technology, nor business plan, nor size explain the evolution of this SME's organizational form. Rather, the associates opted for a new legal structure when they changed their membership or the distribution of the equity. 
Returning to Figure 2, it is clear that the pattern of organizational choice in France at the end of the nineteenth century was similar in its broad outlines to that in the United States. Differences in the two countries' legal regimes do not seem to have played a very important role in shaping businesses' decisions. In both countries, partnerships remained popular in many branches of economic activity long after the corporation had become widely available. In both countries, there were systematic differences across industries in the use of partnerships relative to other organizational forms - differences that seem to have been related to factors such as the relative cost of untimely dissolution versus minority oppression. Moreover, in both countries there was substantial organizational heterogeneity within industries, suggesting that individual characteristics of the business people involved - for example, the wealth constraints highlighted by our model — also played an important role in the choice of organizational form.

\section{Conclusion}

We have argued in this paper that the story of the rise of the corporation is not the tale of the emergence of an inherently superior organizational form. In making this case, it has not been our aim to diminish the contribution of the corporation to the history of economic growth. Indeed, it is difficult to imagine railroads, insurance companies, and many other large important firms operating as partnerships. Rather our aim has been to place the contribution of the corporation in proper perspective. Although corporations did eliminate the problem of untimely dissolution in partnerships, they did so at the cost of facilitating significant minority oppression. For large firms seeking to raise capital on the equity markets, the benefits of incorporation greatly outweighed the costs. But for firms where the number of associates was small and 
investment capital could be obtained more informally, the advantages were not so clear, and the overwhelming majority chose to bear the costs of partnerships rather than to incorporate.

As the scale of enterprise rose during the twentieth century, relatively more firms in the U.S. chose to organize as corporations, especially after World War II when tax and other policy changes accelerated the trend. Elsewhere, however, corporations did not become nearly so dominant. In France the enactment in 1925 of legislation permitting a special form of private limited liability company (the société à responsabilité limitée or SARL) led to the demise of the partnership but also to a significant decline in the proportion of firms taking up the corporate form. Similar legislation passed earlier in Germany (1892) and Britain (1907) had much the same effect. In light of the current literature touting the advantage of common-law over codebased legal regimes, it is interesting to note that in this case continental Europe played the role of leader rather than laggard. U.S. businesses did not obtain a viable version of the SARL until late in the twentieth century (Lamoreaux and Rosenthal 2005).

As we have emphasized in this paper, excessive reliance on very recent data can lead economic theorists astray. But, we hasten to acknowledge, history without theory is just as likely to run amok. Although the two different types of intellectual endeavor can certainly make odd bedfellows, they have important complementary roles to play in the study of economic institutions, and the potential seems to be particularly rich at the intersection of law and business. We hope this paper has demonstrated the value of a long-run historical perspective for understanding the economics of business people's organizational choices. But we also hope that current theoretical debates about corporate governance will help revitalize historical research that all too often been predisposed towards tales of exceptionalism, be they American, British, French, or something else. 


\section{References}

Alchian, Armen A., and Harold Demsetz. 1972. "Production, Information Costs, and Economic Organization.” American Economic Review, 62 (December): 777-95.

Bain, David Haward. 1999. Empire Express: Building the First Transcontinental Railroad. New York: Viking.

Baskin, Jonathan Barron, and Paul J. Miranti, Jr. 1997. A History of Corporate Finance. New York: Cambridge University Press.

Bebchuk, Lucian Arye. 2002. "Asymmetric Information and the Choice of Corporate Arrangements.” Harvard Law School Discussion Paper \#398.

Bebchuk, Lucian Arye, and Allen Ferrell. 1999. "Federalism and Corporate Law: The Race to Protect Managers from Takeovers.” Columbia Law Review, 99 (June): 1168-99.

Blair, Margaret M. 2003. "Locking in Capital: What Corporate Law Achieved for Business Organizers in the Nineteenth Century." UCLA Law Review, 51 (December): 387-455.

Bolton, Patrick, and David Scharfstein. 1998. "Corporate Finance, the Theory of the Firm and Organizations." Journal of Economic Perspectives, 12 (Autumn): 95-114.

Bolton, Patrick, and Ernst-Ludwig Von Thadden. 1998. "Blocks, Liquidity and Corporate Control." Journal of Finance, 53 (February): 1-25.

Brownlee, W. Elliot. 1996. Federal Taxation in America: A Short History. New York: Cambridge University Press.

Cai, Hongbin. 2003. "A Theory of Joint Asset Ownership." Rand Journal of Economics, 34 (Spring): 63-77. 
Carter, Susan, et al. 2006. Historical Statistics of the United States: Millennial Edition. New York: Cambridge University Press.

Cary, William L. 1953. "How Illinois Corporations May Enjoy Partnership Advantages:

Planning for the Closely Held Firm." Northwestern University Law Review, 48 (September-October): 427-41.

Compte général de l'administration de la Justice Civile et Commerciale. Paris: imprimerie nationale, $1840-1933$.

De Juglart, Michel, and Benjamin Ippolito. 1999. Les sociétés commerciales : cours de droit commercial. Paris: Montchrestien.

Demsetz, Harold. 1972. "Wealth Distribution and Ownership Rights." Journal of Legal Studies, 1 (June): 223-232.

Demsetz, Harold, and Kenneth Lehn. 1985. "The Structure of Corporate Ownership: Causes and Consequences." Journal of Political Economy, 93 (December): 1155-77.

Dunlavy, Colleen A. 2004. "From Citizens to Plutocrats: Nineteenth-Century Shareholder Voting Rights and Theories of the Corporation." In Constructing Corporate America: History, Politics, Culture, ed. Kenneth Lipartito and David B. Sicilia. New York: Oxford University Press. Pp. 66-93.

Evans, George Heberton Evans, Jr. 1948. Business Incorporations in the United States, 18001943. New York: National Bureau of Economic Research.

Forbes, Kevin F. 1986. "Limited Liability and the Development of the Business Corporation." Journal of Law, Economics, and Organization, 2 (Spring): 163-77.

Freund, Ernst. 1896. “The Legal Nature of Corporation,” Ph.D. dissertation, Columbia University. 
Gazur, Wayne M., and Neil M. Goff. 1991. "Assessing the Limited Liability Company." Case Western Reserve Law Review, 41 (2): 387-501.

Gazette des tribunaux: Journal de jurisprudence et des débats judiciares. Paris: 1832-1850.

Gower, L. C. B. 1956. "Some Contrasts Between British and American Corporation Law." Harvard Law Review, 69 (June): 1369-1402.

Hansmann, Henry, and Reinier Kraakman. 2000. "The Essential Role of Organizational Law.” Yale Law Journal, 110 (December): 387-440.

Hansmann, Henry, Reinier Kraakman, and Richard Squire. 2004. “Legal Entities, Asset Partitioning, and the Evolution of Organizations. Unpublished paper.

Hart, Oliver. 1995. Firms, Contracts, and Financial Structure. New York: Oxford University Press.

Hornstein, George D. 1950. "Stockholders' Agreements in the Closely Held Corporation." Yale Law Journal, 59 (May): 1040-56.

. 1953. "Judicial Tolerance of the Incorporated Partnership." Law and Contemporary Problems, 18 (Autumn): 435-50.

Howard, Stanley E. 1934. "The Limited Partnership in New Jersey." Journal of Business of the University of Chicago, 7 (October): 296-317.

Hurst, James Willard. 1964. Law and Economic Growth: The Legal History of the Lumber Industry in Wisconsin, 1836-1915. Cambridge, Mass.: Harvard University Press. . 1970. The Legitimacy of the Business Corporation in the Law of the United States, 1780-1970. Charlottesville, Va.: University Press of Virginia.

Lamoreaux, Naomi R., and Jean-Laurent Rosenthal. 2005. "Legal Regime and Contractual Flexibility: A Comparison of Business's Organizational Choices in France and the 
United States during the Era of Industrialization." American Law and Economics Review, 7 (Spring): 28-61.

. 2006. "Corporate Governance and the Plight of Minority Shareholders in the United States before the Great Depression." In Corruption and Reform: Lessons from America's Economic History, eds. Edward Glaeser and Claudia Goldin. Chicago: University of Chicago Press. Pp. 125-52.

La Porta, Rafael, Florencio Lopez-de-Silanes, Andrei Shleifer, and Robert W. Vishny. 1997. “Legal Determinants of External Finance.” Journal of Finance, 52 (July): 1131-50. . 1998. "Law and Finance." Journal of Political Economy, 106 (December): 1113-55.

Lewis, William Draper. 1917. "The Uniform Limited Partnership Act." University of Pennsylvania Law Review, 65 (June): 715-31.

Lyon-Cahen, Ch., and L. Renault. 1924. Manuel de droit commercial (y compris le droit maritime). $14^{\text {th }}$ edn.; Paris: F. Pichon et Durand-Auzias.

Maier, Pauline. 1993. "The Revolutionary Origins of the American Corporation." William and Mary Quarterly, 50 (January): 51-84.

Merle, Philippe. 1998. Droit commercial; sociétés commerciale. $6^{\text {th }}$ edn.; Paris: Dalloz.

Navin, Thomas R., and Marian V. Sears. 1955. “The Rise of a Market for Industrial Stocks, 1887-1902.” Business History Review, 29 (June): 105-38.

O’Neal, F. Hodge. 1953. “Giving Shareholders Power to Veto Corporate Decisions: Use of Special Charter and By-Law Provisions." Law and Contemporary Problems, 18 (Autumn): 451-72. . 1958. Close Corporations: Law and Practice. Chicago: Callaghan. 2 vols. 
. 1965. "Developments in the Regulation of the Close Corporation." Cornell Law Quarterly, 50 (Summer): 641-62.

Pagano, Marco, and Ailsa Roell. 1998. "The Choice of Stock Ownership Structure: Agency Costs, Monitoring, and the Decision to Go Public." Quarterly Journal of Economics, 113 (February): 187-225.

Petska, Thomas B. 1996. "Taxes and Organizational Choice: An Analysis of Trends, 19851992.” SOI Bulletin, 15 (Spring): 86-102. , and Robert A. Wilson. 1994. "Trends in Business Structure and Activity, 1980-1990." SOI Bulletin, 13 (Spring): 27-72.

Pic, Paul, et Baratin, F. 1927. Des SARLs Etude critique et commentaire pratique la loi du 7 mars 1925. Paris: Lib des juris classeurs.

Protection des minoritaires: sociétés ne faisant pas appel public à l'épargne. 2001. Paris: éditions Francis Lefebvre.

Ribstein, Larry E. 2005. "Why Corporations?” Illinois Law and Economics Working Paper No. LE05-011.

Riviere, Hypollite Fereol. 1882. Répétitions écrites sur le code de commerce. $8^{\text {th }}$ edn.; Paris: A. Chevalier-Marescq.

Romano, Roberta. 1987. "The Political Economy of Takeover Statutes." Virginia Law Review, 73 (February): 111-99.

Schwartz, Edward R. 1965. "The Limited Partnership Association-An Alternative to the Corporation for the Small Business with 'Control' Problems?” Rutgers Law Review, 20 (Fall): 29-88. 
Story, Joseph. 1859. Commentaries on the Law of Partnership, as a Branch of Commercial and Maritime Jurisprudence with Occasional Illustrations from the Civil and Foreign Law. $5^{\text {th }}$ edn.; Boston: Little, Brown.

Tirole, Jean. 2001. “Corporate Governance.” Econometrica, 69 (January): 1-35.

Wall, Joseph Frazier. 1970. Andrew Carnegie. New York: Oxford University Press.

Warren, Edward H. 1929. Corporate Advantages without Incorporation. New York: Baker, Voorhis \& Co.

Williamson, Oliver. 1985. The Economic Institutions of Capitalism: Firms Markets, Relational Contracting. New York: Free Press.

Yarrow, George K. 1985. "Shareholder Protection, Compulsory Acquisition and the Efficiency of the Takeover Process." Journal of Industrial Economics. 34 (September): 3-16.

Zingales, Luigi. 1995. "Insider Ownership and the Decision to Go Public." Review of Economic Studies, 62 (July): 425-48.

Zweibel, Jeffrey. 1995. "Block Investment and Partial Benefits of Corporate Control." Review of Economic Studies, 62 (April): 161-85. 
Table 1: Choice of organizational form when shirking is the only problem

\begin{tabular}{|l|l|l|l|l|}
\hline Range of equity & $\mathrm{R}_{\mathrm{c}}$ & & $\mathrm{R}_{\mathrm{p}}$ & Optimal form \\
\hline $\mathrm{S} \leq 1 / 2$ & $\mathrm{R}^{*}-\mathrm{c}_{\mathrm{m}}$ & $=$ & $\mathrm{R}^{*}-\mathrm{c}_{\mathrm{m}}$ & Both \\
\hline $1 / 2<\mathrm{S} \leq \mathrm{S}_{\mathrm{m}}$ & $\mathrm{R}_{0}(\mathrm{~S})$ & $<$ & $\mathrm{R}^{*}-\mathrm{c}_{\mathrm{m}}$ & Partnership \\
\hline $\mathrm{S}>\mathrm{S}_{\mathrm{m}}$ & $\mathrm{R}_{0}(\mathrm{~S})$ & $=$ & $\mathrm{R}_{0}(\mathrm{~S})$ & Both \\
\hline
\end{tabular}

Table 2: Choice of organizational form when untimely dissolution is the only problem

\begin{tabular}{|l|l|l|l|l|}
\hline Range of equity & $\mathrm{R}_{\mathrm{c}}$ & & $\mathrm{R}_{\mathrm{p}}$ & Optimal form \\
\hline $0 \leq \mathrm{S} \leq 1$ & $>$ & $\mathrm{R}^{*}[1-\mathrm{d}]$ & Corporation \\
\hline
\end{tabular}

Table 3: Choice of organizational form when minority oppression is the only problem

\begin{tabular}{|l|l|l|l|l|}
\hline Range of equity & $\mathrm{R}_{\mathrm{c}}$ & & $\mathrm{R}_{\mathrm{p}}$ & Optimal form \\
\hline $\mathrm{S}<1-\mathrm{S}_{\mathrm{ca}}$ & $\mathrm{R}^{*}$ & $=$ & $\mathrm{R}^{*}$ & Both \\
\hline $1-\mathrm{S}_{\mathrm{ca}} \leq \mathrm{S} \leq \mathrm{S}_{\mathrm{ca}}$ & {$[1-\beta] \mathrm{R}^{*}$} & $<$ & $\mathrm{R}^{*}$ & Partnership \\
\hline $\mathrm{S}>\mathrm{S}_{\mathrm{ca}}$ & $\mathrm{R}^{*}$ & $=$ & $\mathrm{R}^{*}$ & Both \\
\hline
\end{tabular}


Table 4: Choice of organizational form when $d<\beta$ and all three transaction costs are present

\begin{tabular}{|l|l|l|l|l|}
\hline Range of equity & $\mathrm{R}_{\mathrm{c}}$ & & $\mathrm{R}_{\mathrm{p}}$ & Optimal form \\
\hline $\mathrm{S}<1-\mathrm{S}_{\mathrm{ca}}$ & $\mathrm{R}^{*}-\mathrm{c}_{\mathrm{m}}$ & $>$ & {$[1-\mathrm{d}] \mathrm{R}^{*}-\mathrm{c}_{\mathrm{m}}$} & Corporation \\
\hline $1-\mathrm{S}_{\mathrm{ca}} \leq \mathrm{S} \leq 1 / 2$ & {$[1-\beta] \mathrm{R}^{*}-\mathrm{c}_{\mathrm{m}}$} & $<$ & {$[1-\mathrm{d}] \mathrm{R}^{*}-\mathrm{c}_{\mathrm{m}}$} & Partnership \\
\hline $1 / 2<\mathrm{S} \leq \mathrm{S}_{\mathrm{m}}$ & {$[1-\beta] \mathrm{R}_{0}(\mathrm{~S})$} & $<$ & {$[1-\mathrm{d}] \mathrm{R}^{*}-\mathrm{c}_{\mathrm{m}}$} & Partnership \\
\hline $\mathrm{S}_{\mathrm{m}}<\mathrm{S} \leq \mathrm{S}_{\mathrm{ca}}$ & {$[1-\beta] \mathrm{R}_{0}(\mathrm{~S})$} & $<$ & {$[1-\mathrm{d}] \mathrm{R}_{0}(\mathrm{~S})$} & Partnership \\
\hline $\mathrm{S}>\mathrm{S}_{\mathrm{ca}}$ & $\mathrm{R}_{0}(\mathrm{~S})$ & $>$ & {$[1-\mathrm{d}] \mathrm{R}_{0}(\mathrm{~S})$} & Corporation \\
\hline
\end{tabular}

Table 5: Choice of organizational form when $d \geq \beta,[1-\beta] R_{c 0 a}(1 / 2)<[1-d] R^{*}-c_{m}$ and all three transaction costs are present

\begin{tabular}{|l|l|l|l|l|}
\hline Range of equity & $\mathrm{R}_{\mathrm{c}}$ & & $\mathrm{R}_{\mathrm{p}}$ & Optimal form \\
\hline $\mathrm{S}<1-\mathrm{S}_{\mathrm{ca}}$ & $\mathrm{R}^{*}-\mathrm{c}_{\mathrm{m}}$ & $>$ & {$[1-\mathrm{d}] \mathrm{R}^{*}-\mathrm{c}_{\mathrm{m}}$} & Corporation \\
\hline $1-\mathrm{S}_{\mathrm{ca}} \leq \mathrm{S} \leq 1 / 2$ & {$[1-\beta] \mathrm{R}^{*}-\mathrm{c}_{\mathrm{m}}$} & $>$ & {$[1-\mathrm{d}] \mathrm{R}^{*}-\mathrm{c}_{\mathrm{m}}$} & Corporation \\
\hline $1 / 2<\mathrm{S} \leq \mathrm{S}^{\prime}$ & {$[1-\beta] \mathrm{R}_{0}(\mathrm{~S})$} & $<$ & {$[1-\mathrm{d}] \mathrm{R}^{*}-\mathrm{c}_{\mathrm{m}}$} & Partnership \\
\hline $1 / 2<\mathrm{S} \leq \mathrm{S}^{\prime}$ & {$[1-\beta] \mathrm{R}_{0}(\mathrm{~S})$} & $>$ & {$[1-\mathrm{d}] \mathrm{R}^{*}-\mathrm{c}_{\mathrm{m}}$} & Corporation \\
\hline $\mathrm{S}^{\prime}<\mathrm{S} \leq \mathrm{S}_{\mathrm{ca}}$ & {$[1-\beta] \mathrm{R}_{0}(\mathrm{~S})$} & $>$ & {$[1-\mathrm{d}] \mathrm{R}_{0}(\mathrm{~S})$} & Corporation \\
\hline $\mathrm{S}>\mathrm{S}_{\mathrm{ca}}$ & $\mathrm{R}_{0}(\mathrm{~S})$ & $>$ & {$[1-\mathrm{d}] \mathrm{R}_{0}(\mathrm{~S})$} & Corporation \\
\hline
\end{tabular}

Table 6: Choice of organizational form when $d \geq \beta,[1-\beta] R_{c 0 a}(1 / 2) \geq[1-d] R^{*}-c_{m}$, and all three transaction costs are present

\begin{tabular}{|l|l|l|l|l|}
\hline Range of equity & $\mathrm{R}_{\mathrm{c}}$ & & $\mathrm{R}_{\mathrm{p}}$ & Optimal form \\
\hline $\mathrm{S}<1-\mathrm{S}_{\mathrm{ca}}$ & $\mathrm{R}^{*}-\mathrm{c}_{\mathrm{m}}$ & $>$ & {$[1-\mathrm{d}] \mathrm{R}^{*}-\mathrm{c}_{\mathrm{m}}$} & Corporation \\
\hline $1-\mathrm{S}_{\mathrm{ca}} \leq \mathrm{S} \leq 1 / 2$ & {$[1-\beta] \mathrm{R}^{*}-\mathrm{c}_{\mathrm{m}}$} & $>$ & {$[1-\mathrm{d}] \mathrm{R}^{*}-\mathrm{c}_{\mathrm{m}}$} & Corporation \\
\hline $1 / 2<\mathrm{S} \leq \mathrm{S}_{\mathrm{m}}$ & {$[1-\beta] \mathrm{R}_{0}(\mathrm{~S})$} & $>$ & {$[1-\mathrm{d}] \mathrm{R}^{*}-\mathrm{c}_{\mathrm{m}}$} & Corporation \\
\hline $\mathrm{S}_{\mathrm{m}}<\mathrm{S} \leq \mathrm{S}_{\mathrm{ca}}$ & {$[1-\beta] \mathrm{R}_{0}(\mathrm{~S})$} & $>$ & {$[1-\mathrm{d}] \mathrm{R}_{0}(\mathrm{~S})$} & Corporation \\
\hline $\mathrm{S}>\mathrm{S}_{\mathrm{ca}}$ & $\mathrm{R}_{0}(\mathrm{~S})$ & $>$ & {$[1-\mathrm{d}] \mathrm{R}_{0}(\mathrm{~S})$} & Corporation \\
\hline
\end{tabular}


Table 7: Explaining the share of partnerships among U.S. manufacturing firms in 1900

\begin{tabular}{|c|c|c|c|c|c|c|c|c|c|c|}
\hline & \multicolumn{10}{|c|}{ Share of partnerships } \\
\hline & \multicolumn{6}{|c|}{ OLS Regressions } & \multicolumn{4}{|c|}{ Tobit Regressions } \\
\hline & $(1)$ & $(2)$ & $(3)$ & $(4)$ & $(5)$ & $(6)$ & $(6)$ & $(7)$ & $(8)$ & (9) \\
\hline Constant & $1.65 *$ & $0.84 *$ & $1.61 *$ & $1.188^{*}$ & $1.243^{*}$ & $1.386^{*}$ & $1.96^{*}$ & $1.83 *$ & $1.83 *$ & $1.90 *$ \\
\hline Ln Capital/ Establishment & $-0.11 *$ & & $-0.100 *$ & $-0.055 *$ & $-0.064 *$ & $-0.075^{*}$ & $-0.13^{*}$ & $-0.13^{*}$ & $-0.13^{*}$ & $-0.14 *$ \\
\hline LN Employment/ Establishment & & $-0.10 *$ & $-0.013 *$ & $-0.029 *$ & $-0.026^{*}$ & $-0.017 *$ & $-0.02 *$ & $-0.03 *$ & $-0.03 *$ & $-0.02 *$ \\
\hline $\begin{array}{l}\text { Ln Capital/ Establishment X } \\
\text { Manufacturing belt dummy }\end{array}$ & & & & & $0.008^{*}$ & & & & $0.008^{*}$ & \\
\hline State F.E. & No & No & No & No & No & Yes & & & & \\
\hline Industry F.E. & No & No & No & Yes & Yes & Yes & & & & \\
\hline Region F.E. & & & & & & & No & Yes & No & Yes \\
\hline Sector FE & & & & & & & No & No & Yes & Yes \\
\hline $\mathrm{N}$ & 4924 & 4736 & 4736 & 4736 & 4736 & 4736 & 4736 & 4736 & 736 & 4736 \\
\hline $\mathrm{R}^{2}$ & 0.35 & 0.24 & 0.36 & 0.55 & 0.55 & 0.60 & & & & \\
\hline $\operatorname{adj}^{2}$ & 0.35 & 0.24 & 0.36 & 0.51 & 0.53 & 0.57 & & & & \\
\hline Pseudo $\mathrm{R}^{2}$ & & & & & & & 0.26 & 0.29 & .29 & .31 \\
\hline
\end{tabular}

Notes: An observation is an industry in a given state. The dependent variable is the share of partnerships in multi-owner firms. The independent variables aggregate all of the firms in the industry in a given state, including sole proprietorships.

Ln Capital/Establishment is reported capital divided by number of establishments. Ln Employment/Establishment is reported average employment (including managers) divided by number of establishments. Manufacturing belt is a dummy variable that takes on the value 1 if the industry is in CN, IL, IN, MA, NY, NJ, OH, PA RI.

Columns 1-5 report OLS results, and 6 and 7 report Tobit regressions for two-sided censoring. The Tobit regressions do not converge when state and industry fixed effects are included, so region and sector fixed effects were used instead.

Source: U.S. Census of Manufacturing: 1900, Vol. VII, Table 4, pp. 66-465, and Table 9, pp. 511-580. 
Table 8: Distribution of multi-owner establishments in U.S. Manufacturing, 1900

$\begin{array}{cccccc}\begin{array}{c}\text { Fraction of Multi-owner } \\ \text { Establishments } \\ \text { that are partnerships }\end{array} & \begin{array}{c}\text { Multi-owner } \\ \text { Establishments } \\ (\%)\end{array} & \begin{array}{c}\text { All } \\ \text { Establishments }\end{array} & \begin{array}{c}\text { Capital } \\ (\%)\end{array} & \begin{array}{c}\text { Workers } \\ (\%)\end{array} & \begin{array}{c}\text { Added } \\ \text { (\%) }\end{array} \\ 0.01 \text { to } 10 & 0.017 & 0.005 & 0.110 & 0.037 & 0.067 \\ 10.1 \text { to } 20 & 0.023 & 0.008 & 0.098 & 0.059 & 0.089 \\ 20.1 \text { to } 30 & 0.032 & 0.012 & 0.082 & 0.043 & 0.069 \\ 30.1 \text { to } 40 & 0.058 & 0.028 & 0.100 & 0.077 & 0.090 \\ 40.1 \text { to } 50 & 0.066 & 0.037 & 0.084 & 0.070 & 0.089 \\ 50.1 \text { to } 60 & 0.069 & 0.040 & 0.088 & 0.064 & 0.075 \\ 60.1 \text { to } 70 & 0.086 & 0.056 & 0.084 & 0.120 & 0.077 \\ 70.1 \text { to } 80 & 0.124 & 0.101 & 0.079 & 0.184 & 0.099 \\ 80.1 \text { to } 90 & 0.227 & 0.253 & 0.090 & 0.121 & 0.129 \\ 90.1 \text { to } 99.9 & 0.263 & 0.387 & 0.064 & 0.122 & 0.121 \\ 100 & 0.034 & 0.061 & 0.008 & 0.019 & 0.017 \\ \text { Total } & 130861 & 505945 & 9304 & 6110 & 5295\end{array}$

Note: The data for the table come from merging the two published tables cited below. Establishments are the numbers reported. Capital is in millions of dollars, and workers are in thousands.

Source: U.S. Census of Manufacturing: 1900, Vol. VII, Table 4, pp. 66-465, and Table 9, pp. 511-580. 
Table 9: New multi-owner firms registered in Paris, 1833-1850, broken down by sector and organizational form

\begin{tabular}{|c|c|c|c|c|c|c|c|c|}
\hline & $\mathrm{N}$ & Artisans & Trade & $\begin{array}{l}\text { Construction } \\
\text { and real } \\
\text { estate }\end{array}$ & Manufacturing & $\begin{array}{c}\text { Mining } \\
\text { and } \\
\text { agriculture }\end{array}$ & Services & Transport \\
\hline Partnership & 7458 & 353 & 3108 & 214 & 2715 & 67 & 765 & 164 \\
\hline Silent partnership & 2065 & 67 & 774 & 42 & 737 & 23 & 349 & 43 \\
\hline $\begin{array}{l}\text { Silent partnership } \\
\text { with tradable shares }\end{array}$ & 2486 & 30 & 166 & 104 & 775 & 243 & 943 & 202 \\
\hline Corporations & 26 & & & 2 & 5 & 5 & 9 & 5 \\
\hline Other & 97 & 2 & 14 & 11 & 27 & 17 & 19 & 7 \\
\hline $\begin{array}{l}\text { Total Firms } \\
\text { Share of }\end{array}$ & 12132 & 452 & 4062 & 373 & 4259 & 355 & 2085 & 418 \\
\hline Partnerships & 0.61 & 0.78 & 0.77 & 0.57 & 0.64 & 0.19 & 0.37 & 0.39 \\
\hline
\end{tabular}

Note and source: The table reports the organizational forms adopted by all firms that published a summary of their organizational charter in the Gazette des Tribunaux from January 1, 1833, to December 31, 1850.

Table 10: Transition matrix for Parisian firms that changed organizational form

$\begin{array}{llcccc} & & \text { Reorganized form } & & \\ & & \mathrm{P} & \mathrm{CS} & \mathrm{CA} & \text { Other } \\ \text { Initial } & \text { Partnerships } & 518 & 97 & 62 & 5 \\ \text { Form } & \text { Commandite Simple } & 62 & 89 & 19 & 2 \\ & \text { Commandite par Actions } & 94 & 38 & 172 & 2 \\ & \text { Other } & 6 & 1 & 1 & 4\end{array}$

Note and source: The table includes all firms that published a summary of their organizational charter in the Gazette des Tribunaux from January 1, 1833, to December 31, 1850, for which we were able to trace a successor firm that was also a multi-owner firm. 
Figure 1: Choice of Organization when Shirking is the Only Transaction Cost.

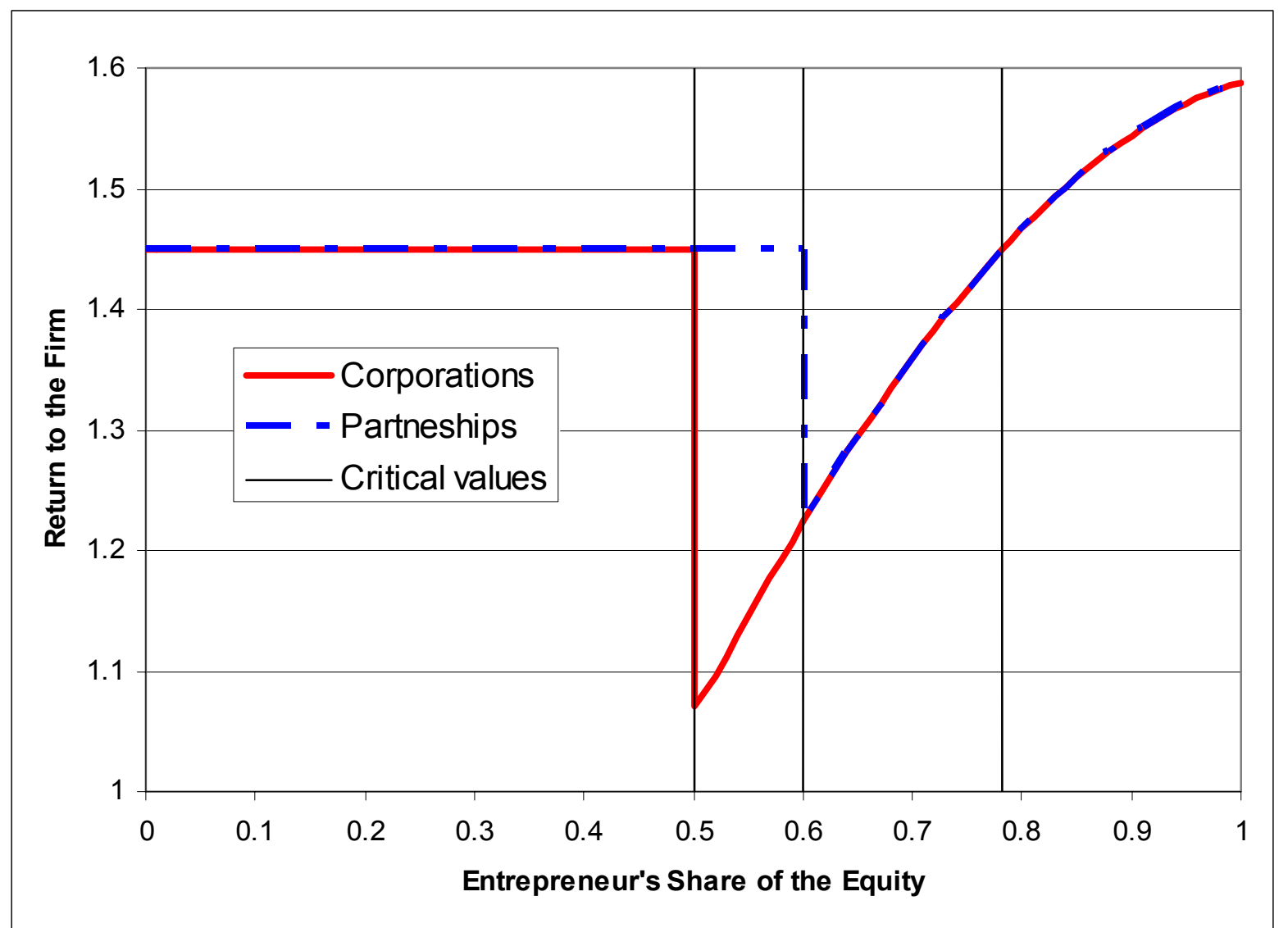

Note: the values on the vertical axis are purely for illustration. 
Figure 2: Numbers of New Multiowner in Paris 1833-1823

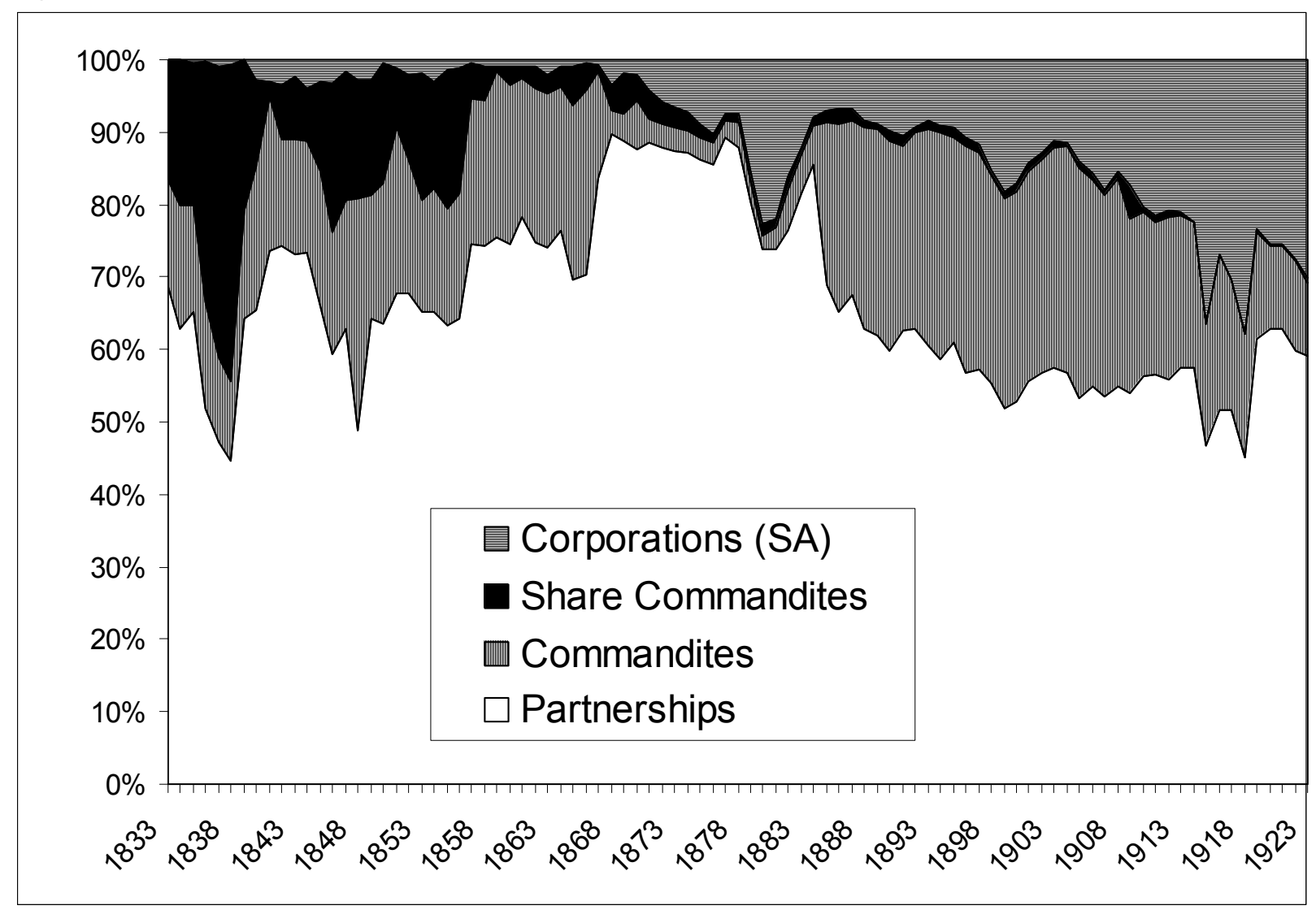

Source: For 1833 to 1840 Gazette des Tribunaux, for 1841-1969, 1875-1913 and 1919-23 annual issues of the Compte général de l'administration de la justice civile et commerciale, for 1914-1918 Archives de Paris, Serie U. 


\section{Appendix}

Proposition 5: Firms with very high or very low returns have the fewest governance problems.

High returns correspond to high $\Pi, \mathrm{L}$, or $\mathrm{p}^{*}$.

Part 1: returns are large

Denote by $\mathrm{S}^{\sim}$ the maximum of $\mathrm{S}_{\mathrm{pm}}$ and $\mathrm{S}_{\mathrm{ca}}$ if $\Pi, \mathrm{L}$, or $\mathrm{p}^{*}$ is large enough then

$\left[1-S^{\sim}\right] R\left(S^{\sim}\right)>[1+r]$, As a result, even if the entrepreneur invests nothing, the firm can operate as a corporation controlled by the entrepreneur without any minority oppression and with returns sufficiently high that it is not worthwhile to monitor.

Part 2: Returns are very low

The best the firm can earn is $\mathrm{R}^{*}=\mathrm{p}^{*} \Pi+\left[1-\mathrm{p}^{*}\right] \mathrm{L}-\mathrm{w}$. If $\mathrm{R}^{*}$ is close enough to $1+\mathrm{r}$, then $\mathrm{R}^{*}[1-\mathrm{d}]<(1+\mathrm{r})$, and the firm cannot operate as a partnership. Similarly, $\mathrm{R}^{*}[1-\beta]<(1+\mathrm{r})$, and it will not be able to operate as a corporation with minority oppression. If $\mathrm{R}^{*}$ is small enough, therefore, the firm will only be able to operate if it is a corporation with one associate owning at least $\mathrm{S}_{\mathrm{ca}}$ of the firm. Obviously, if wealth constraints bind, many low-return firms will not form because neither partner has sufficient funds to own enough of the firm to eliminate transaction costs.

Proposition 6: Some equity stakes are never offered in equilibrium, in particular those that are slightly larger than $\left(1-\mathrm{S}_{\mathrm{ca}}\right), 1 / 2$, and $\mathrm{S}_{\mathrm{pm}}$ as well as those that are slightly smaller than $\mathrm{S}_{\mathrm{ca}}$.

Begin by assuming that the efficient form is a corporation as long as the equity stake of the entrepreneur is less than $\mathrm{S}_{\mathrm{ca}}$, and that it is a partnership for stakes between $\mathrm{S}_{\mathrm{ca}}$ and $1 / 2$. For the investor to buy $\mathrm{S}_{\mathrm{ca}}$ his wealth must be $\hat{\mathrm{W}}_{\mathrm{i}}=\left[\mathrm{S}_{\mathrm{ca}}\left[\mathrm{R}^{*}\right]-\mathrm{c}_{\mathrm{m}}\right] /[1+\mathrm{r}]$. The entrepreneur's return is $[1-$ 
$\left.\mathrm{S}_{\mathrm{ca}}\right] \mathrm{R}^{*}$. If the investor's wealth is less than $\hat{\mathrm{W}}_{\mathrm{i}}$, the entrepreneur has two choices. She can organize the firm as a partnership in which the investor's stake would be $S_{i}=[1+r]\left[W_{i}+c_{m}\right] / R^{*}(1-$ d) and the entrepreneur's return would be $\mathrm{R}_{\mathrm{ep}}\left(\mathrm{S}_{\mathrm{i}}, \mathrm{W}_{\mathrm{i}}\right)=\left[1-\mathrm{S}_{\mathrm{i}}\right] \mathrm{R}^{*}[1-\mathrm{d}]$. Or she can organize the firm as a corporation and give the investor $\mathrm{S}_{\mathrm{ca}}$ to avoid the cost of minority oppression. Her earnings then would be $\mathrm{R}_{\mathrm{ep}}\left(\mathrm{S}_{\mathrm{ca}}, \mathrm{W}_{\mathrm{i}}\right)=\left[1-\mathrm{S}_{\mathrm{ca}}\right] \mathrm{R}^{*}$. If $\mathrm{W}_{\mathrm{i}}$ is sufficiently close to $\left[\mathrm{S}_{\mathrm{ca}}\left[\mathrm{R}^{*}\right]-\mathrm{c}_{\mathrm{m}}\right] /[1+\mathrm{r}]$, then $\mathrm{R}_{\mathrm{ep}}\left(\mathrm{S}_{\mathrm{ca}}, \mathrm{W}_{\mathrm{i}}\right)>\mathrm{R}_{\mathrm{ep}}\left(\mathrm{S}_{\mathrm{i}}, \mathrm{W}_{\mathrm{i}}\right)$ and the entrepreneur prefers to 'give' some equity away to avoid transaction costs. She will do so at least until $\mathrm{W}_{\mathrm{ip}}=\left[\mathrm{S}_{\mathrm{ca}} \mathrm{R}^{*}(1-\mathrm{d})-\mathrm{c}_{\mathrm{m}}\right] /[1+\mathrm{r}]$. Clearly $\mathrm{W}_{\mathrm{ip}}<\hat{\mathrm{W}}_{\mathrm{i}}$. Hence we have shown that the wealth to equity stakes correspondence has a flat spot at $\mathrm{S}_{\mathrm{ca}}$.

One can show that similar flat spots arise under other assumptions. They occur at $\mathrm{S}=1$ $\mathrm{S}_{\mathrm{ca}}$, even if corporations are preferred to partnerships; at $\mathrm{S}=1 / 2$ whenever corporations are preferred from $\mathrm{S}_{\mathrm{ca}}<\mathrm{S}<1 / 2$ but not for $\mathrm{S}>1 / 2$; and at $\mathrm{S}=\mathrm{S}_{\mathrm{ca}}$. Further, one can show for all these cases that at the point where the flat spot ends, the correspondence between wealth and equity stakes jumps.

Returning to the case where $S=1-S_{c a}$, the entrepreneur continues to offer the investor $S_{c a}$ until $\mathrm{R}_{\mathrm{ep}}\left(\mathrm{S}_{\mathrm{ca}}, \mathrm{W}_{\mathrm{i}}\right)=\mathrm{R}_{\mathrm{ep}}\left(\mathrm{S}_{\mathrm{i}}, \mathrm{W}_{\mathrm{i}}\right)$ or $\left[1-\mathrm{S}_{\mathrm{ca}}\right] \mathrm{R}^{*}=\left[1-\mathrm{S}_{\mathrm{i}}\right] \mathrm{R}^{*}[1-\mathrm{d}]$. Taking differences leads to [1- $\left.\mathrm{S}_{\mathrm{i}}\right] \mathrm{R}^{*}[1-$ $\mathrm{d}]=\left[1-\mathrm{S}_{\mathrm{ca}}\right] \mathrm{R}^{*}$, or $\left[1-\mathrm{S}_{\mathrm{i}}\right]=\left[1-\mathrm{S}_{\mathrm{ca}}\right] /[1-\mathrm{d}]$. Because $[1-\mathrm{d}]<1,\left[1-\mathrm{S}_{\mathrm{i}}\right]>\left[1-\mathrm{S}_{\mathrm{ca}}\right]$, and that implies $\mathrm{S}_{\mathrm{i}}<\mathrm{S}_{\mathrm{ca}}$. Again, similar calculations can be performed for the other cases.

Proposition 7: As d and $\beta$ increase, firms where investment stakes are relatively equal are less likely to form.

Recall that $\mathrm{S}$ is increasing in $\mathrm{W}_{\mathrm{e}}$, except where the return function has jumps. If we start from an extreme wealth distribution (say $\mathrm{W}_{\mathrm{e}}$ equal to 1 ) and begin to increase the investor's wealth, investment stakes will first become more even and then less so. If $\Pi$ is not too large, 
equity stakes will follow the same U-shaped pattern. We already know that aggregate returns follow a U-shaped pattern (higher with extreme equity stakes than with more even one). As d increases, returns fall everywhere, but the first place for the aggregate participation constraint to bind is at the bottom of the aggregate return curve (that is, where equity stakes are more even). Hence the result that firms with even equity stakes are most sensitive to transactions costs is straightforward.

Because the entrepreneur is the residual claimant, her investment stake is typically smaller than her equity stake. If profits are small enough, however, the difference will be small, and even equity stakes will correspond to even investment stakes. Hence as $d$ and $\beta$ increase, the resulting fall in aggregate returns directly reduces the capacity of firms to form. It also has an indirect effect on the formation of firms because the entrepreneur needs to surrender more equity to secure the investor's participation, increasing the likelihood of even equity stakes where transactions costs are most severe.

Proposition 8: If $\mathrm{R}^{*}$ and $\mathrm{d}$ are small enough, for two intervals of entrepreneur wealth $\left\{1, \mathrm{~W}_{\mathrm{e} 1}\right\}$; $\left\{\mathrm{W}_{\mathrm{e} 2}, 0\right\}$ the firm is organized as a corporation. For wealth between $\mathrm{W}_{\mathrm{e} 1}$ and $\mathrm{W}_{\mathrm{e} 2}$ the firm does not form. As $\Pi$ increases, the range where the firm does not form shrinks and ultimately disappears and there will be a middle range of entrepreneur wealth such that the firm is organized as a partnership. As $\Pi$ increases further the lower range of wealth levels where the firm is organized as a corporation will disappear, then the range at which is organized as a partnership will also disappear. If $\Pi$ is large enough the firm operates as a corporation under the entrepreneur's control whatever the initial wealth endowment.

Assume $\mathrm{d}<\beta$. 
- $\quad$ Let $\mathrm{R}^{*}-\mathrm{c}_{\mathrm{m}}>1+\mathrm{r}$ and $(1-\mathrm{d}) \mathrm{R}^{*}-\mathrm{c}_{\mathrm{m}}<1+\mathrm{r}$.

Then the firm will form only if the equity distribution is such that the firm can operate as a corporation without appropriation. That implies that $\mathrm{S}>\mathrm{S}_{\mathrm{ca}}$ or $\mathrm{S}<1-\mathrm{S}_{\mathrm{ca}}$. The largest investment the investor is willing to make if he receives $1-\mathrm{S}_{\mathrm{ca}}$ is $\mathrm{W}_{\mathrm{i}}=\left[1-\mathrm{S}_{\mathrm{ca}}\right] \mathrm{R}^{*}\left(\mathrm{~S}_{\mathrm{ca}}\right) /[1+\mathrm{r}]$. Hence $\mathrm{W}_{\mathrm{el}}=1-\left[1-\mathrm{S}_{\mathrm{ca}}\right] \mathrm{R}^{*}\left(\mathrm{~S}_{\mathrm{ca}}\right) /[1+\mathrm{r}]$. At the other extreme, the largest investment the entrepreneur is willing to make if she receives $1-\mathrm{S}_{\mathrm{ca}}$ is $\mathrm{W}_{\mathrm{e} 2}=\left[1-\mathrm{S}_{\mathrm{ca}}\right] \mathrm{R}^{*} /[1+\mathrm{r}]$

- $\quad$ Now increase $\Pi$ so that $(1-\mathrm{d}) \mathrm{R}^{*}-\mathrm{c}_{\mathrm{m}}>1+\mathrm{r}$. By definition there must exist an $\mathrm{S}_{\mathrm{m}}$, the largest equity stake for the entrepreneur that will elicit monitoring. Assume that $(1-d) R_{p 0}\left(S_{m}\right)<1+r$. That is, the absence of monitoring the firm does not form between $\mathrm{S}_{\mathrm{m}}$ and $\mathrm{S}_{\mathrm{ca}}$. We can also define $\mathrm{S}$ ' such that $(1-d) R_{p 0}\left(S^{\prime}\right)=1+r . S^{\prime}$ is the smallest equity stake that will allow firm to operate as a partnership without monitoring.

Then the firm will form as a corporation if $\mathrm{W}_{\mathrm{e}}<\left(1-\mathrm{S}_{\mathrm{ca}}\right) \mathrm{R}^{*} /[1+\mathrm{r}]$ or $\mathrm{W}_{\mathrm{e}}>1-(1-$ $\left.\mathrm{S}_{\mathrm{ca}}\right) \mathrm{R}\left(\mathrm{S}_{\mathrm{ca}}\right) /[1+\mathrm{r}]$. It will also form as a partnership for any $\mathrm{W}_{\mathrm{e}}$ such that $\mathrm{S}<\mathrm{S}_{\mathrm{m}}$. The largest investment the entrepreneur is willing to make for a stake of $S_{m}$ is $W_{e}=S_{m}(1-d) R^{*} /[1+r]$. That investment defines $\mathrm{W}_{\mathrm{e} 2}$.

At $\mathrm{S}^{\prime}$ there is no monitoring. The return to the investor is [1-S']R(S')[1-d], and the aggregate return is $R\left(S^{\prime}\right)[1-d]=1+r$. The largest investment the investor is willing to make for a stake of 1-S 'is 1-S'. Hence the firm will operate for all investment stakes between 0 and $\mathrm{S}_{\mathrm{m}}(1-$ d) $\mathrm{R}^{*} /[1+\mathrm{r}]$ and between $\mathrm{S}^{\prime}$ and 1 . At the extremes it is a corporation. Otherwise, when it operates, it is a partnership.

- $\quad$ Now increase $\Pi$ such that $(1-d) R_{p 0}\left(S_{m}\right)-c_{m}>1+r$. Then the investor's participation constraint will never bind, and the firm will operate regardless of the initial distribution of 
wealth. What form the firm takes depends on what maximizes the return of the entrepreneur. If $1>\left[\mathrm{S}_{\mathrm{ca}} \mathrm{R}^{*}-\mathrm{c}_{\mathrm{m}}\right] /[1+\mathrm{r}]$, the firm will form as a corporation until $\mathrm{W}_{\mathrm{e}}=\left(1-\mathrm{S}_{\mathrm{ca}}\right) \mathrm{R}^{*} /[1+\mathrm{r}]$. It then switches to a partnership until $\mathrm{W}_{\mathrm{e}}=1-\left(1-\mathrm{S}_{\mathrm{ca}}\right) \mathrm{R}\left(\mathrm{S}_{\mathrm{ca}}\right) /[1+\mathrm{r}]$. Then it switches back to a corporation.

If $1<\left[\mathrm{S}_{\mathrm{ca}} \mathrm{R}^{*}-\mathrm{c}_{\mathrm{m}}\right] /[1+\mathrm{r}]$, the investor with wealth $\mathrm{W}_{\mathrm{i}}<1$ can never buy enough of the firm to operate without appropriating returns, even if he makes the whole of the required investment. If $\mathrm{W}_{\mathrm{e}} \geq 1-\left(1-\mathrm{S}_{\mathrm{ca}}\right) \mathrm{R}\left(\mathrm{S}_{\mathrm{ca}}\right) /[1+\mathrm{r}]$, the firm operates as a corporation and there is no minority oppression. If $\mathrm{W}_{\mathrm{e}}<1-\left(1-\mathrm{S}_{\mathrm{ca}}\right) \mathrm{R}\left(\mathrm{S}_{\mathrm{ca}}\right) /[1+\mathrm{r}]$, then the entrepreneur cannot avoid all transactions costs. She will operate the firm as a partnership (because $d<\beta$ ). Once the investor becomes rich enough, the entrepreneur may decide to 'give' the investor some extra equity as we saw in proposition 6. But that will occur only if $1-\mathrm{S}_{\mathrm{ca}}>\left[1-\left[[1+\mathrm{r}] /[1-\mathrm{d}] \mathrm{R}^{*}\right]\right][1-\mathrm{d}]$. If not, the firm operates as a corporation when the entrepreneur has a stake larger than $\mathrm{S}_{\mathrm{ca}}$ and as a partnership otherwise.

Finally, if we increase $\Pi$ such that $\mathrm{R}_{\mathrm{c} 0}\left(\mathrm{~S}_{\mathrm{ca}}\right)>1+\mathrm{r} /\left[1-\mathrm{S}_{\mathrm{ca}}\right]$, then the entrepreneur raises all the capital she needs while maintaining such a high equity share that the firm always operates as a corporation with no transaction costs.

The proof of $d>\beta$ is similar.

Proposition 9: The first best outcome $\left(\mathrm{R}=\mathrm{R}^{*}\right)$ cannot only be reached if wealth constraints are fully relaxed. When the first best cannot be reached, the firm will be either a partnership or a corporation depending on the relative intensity of the various transaction costs and the relative wealth of the two associates. Holding one associate's wealth constant, aggregate returns are weakly increasing in the wealth of the other.

If $\mathrm{W}_{\mathrm{e}} \geq 1$, then $\mathrm{R}=\mathrm{R}^{*}$. This is the first best outcome. In all other cases at least one transaction cost will have to be borne. If $\mathrm{W}_{\mathrm{i}} \geq \mathrm{S}_{\mathrm{ca}} \mathrm{R}^{*} /[1+\mathrm{r}]$, then $\mathrm{R}=\mathrm{R}^{*}-\mathrm{c}_{\mathrm{m}}$, This is the best outcome 
if the investor 'owns' the firm. If $\mathrm{W}_{\mathrm{i}}<\mathrm{S}_{\mathrm{ca}} \mathrm{R}^{*} /[1+\mathrm{r}]$ or $\mathrm{W}_{\mathrm{e}}<1-\left(1-\mathrm{S}_{\mathrm{ca}}\right) \mathrm{R}\left(\mathrm{S}_{\mathrm{ca}}\right) /[1+\mathrm{r}]$, then the firm will also bear either dissolution or appropriation costs.

The second part of the proposition is trivial. Start with any wealth distribution $\left\{\mathrm{W}_{\mathrm{e}} \mathrm{W}_{\mathrm{i}}\right\}$. The firm is defined by an organizational form (partnership or corporation) and a distribution of equity. If we increase $\mathrm{W}_{\mathrm{e}}$ holding $\mathrm{W}_{\mathrm{i}}$ constant, the entrepreneur can still create the firm as it was organized before but now has additional options (in particular she can choose to keep a larger stake). Because the entrepreneur is the residual claimant, she will only do so if aggregate returns increase. The argument is symmetric if we increase $\mathrm{W}_{\mathrm{i}}$ instead. 